\title{
TINJAUAN SISTEM PENGENDALIAN INTERN TERHADAP PENERIMAAN DAN PENGELUARAN KAS
}

\section{Studi kasus pada Pusat Penelitian dan Pengembangan Peternakan (KEMENTERIAN PERTANIAN)}

TUGAS AKHIR

Oleh:

RITA RIA SONNATA

NPM : 12900059

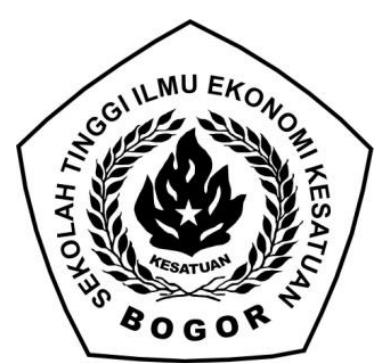

PROGRAM DIPLOMA III AKUNTANSI

SEKOLAH TINGGI ILMU EKONOMI KESATUAN

BOGOR

2015 


\section{TINJAUAN SISTEM PENGENDALIAN INTERN TERHADAP PENERIMAAN DAN}

\section{PENGELUARAN KAS}

Studi kasus pada Pusat Penelitian dan Pengembangan Peternakan (KEMENTERIAN PERTANIAN)

TUGAS AKHIR

Tugas Akhir

sebagai salah satu syarat untuk memperoleh

gelar Ahli Madya pada Program Studi Akuntansi

Sekolah Tinggi Ilmu Ekonomi Kesatuan

Oleh:

RITA RIA SONNATA

NPM : 12900059

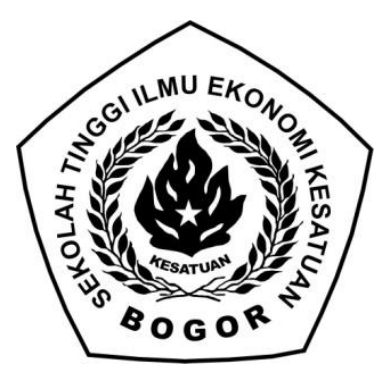

PROGRAM DIPLOMA III AKUNTANSI

SEKOLAH TINGGI ILMU EKONOMI KESATUAN

BOGOR

2015 


\title{
TINJAUAN SISTEM PENGENDALIAN INTERN TERHADAP PENERIMAAN DAN
}

\section{PENGELUARAN KAS}

\section{Studi kasus pada Pusat Penelitian dan Pengembangan Peternakan (KEMENTERIAN PERTANIAN)}

\author{
TUGAS AKHIR
}

\author{
Telah diujikan dan disetujui pada sidang Ahli Madya \\ Sekolah Tinggi Ilmu Ekonomi Kesatuan pada, \\ Hari : Rabu \\ Tanggal : 30 September 2015
}

Mengetahui,

Ketua STIE Kesatuan

Nusa Muktiadji, Ir., MM.
Ketua Program Studi Akuntansi STIE Kesatuan

Yayuk Nurjanah, SE., M.Ak. 


\title{
TINJAUAN SISTEM PENGENDALIAN INTERN TERHADAP PENERIMAAN DAN
}

\author{
PENGELUARAN KAS \\ Studi Kasus pada Pusat Penelitian dan Pengembangan Peternakan \\ (KEMENTERIAN PERTANIAN) \\ TUGAS AKHIR
}

Telah disetujui oleh Pembimbing

Rini Yuli Prihatin, SE., M.Ak.

\author{
Telah diujikan pada sidang ahli madya dan \\ Dinyatakan LULUS pada tanggal \\ seperti tertera di bawah ini
}

Bogor, 30 September 2015

Penguji I

Penguji II

Siti Ita Rosita, SE., MM., SAS

Hj. Tri Marlina, SE., M.Ak 
RITA RIA SONNATA. NPM : 12900059. Tinjauan Sistem Pengendalian Intern Terhadap Penerimaaan dan Pengeluaran Kas. Studi kasus pada Pusat Penelitian dan Pengembangan Peternakan. Dibawah bimbingan RINI YULI PRIHATIN.

Dalam melaksanakan kegiatan perusahaan sehari-hari, dibutuhkan sebuah sistem dan prosedur yang dapat membantu perusahaan dalam hal penerimaan dan pengeluaran yang berkaitan dengan kas, sehingga perusahaan dapat berjalan dengan baik dan efisien. Kas adalah saldo perusahaan yang berasal dari penghasilan yang akan disetor ke bank dan dapat diambil sewaktu-waktu guna membiayai pengeluaran perusahaan.

Maksud dari pembuatan tugas akhir ini adalah untuk memperoleh data yang relevan serta gambaran mengenai penerimaan dan pengeluaran kas. Peninjauan yang dilakukan oleh penulis adalah Pusat Penelitian dan Pengembangan Peternakan yang berlokasi di Jalan Pajajaran Kav. E 59 Bogor. Pusat Penelitian dan Pengembangan Peternakan adalah satuan unit kerja yang berada di bawah Kementerian Pertanian yang bergerak di Bidang Strategi Inovasi dan Penelitian Teknologi Tinggi Peternakan dan Veteriner.

Hasil peninjauan menunjukan bahwa sistem penerimaan dan pengeluaran kas pada Pusat Penelitian dan Pengembangan Peternakan secara umum baik, namun masih ada poin-poin tertentu yang dinilai belum cukup baik yaitu belum dibentuknya fungsi pemeriksaan intern terhadap saldo kas serta adanya penggabungan fungsi pada fungsi kas, padahal fungsi ini memiliki kerentanan yang tinggi terhadap penyelewengan. Adahal yang perlu ditambahkan, bahwa sebaiknya dalam penyelenggaraan kas kecil pada Pusat Penelitian dan Pengembangan Peternakan menggunakan imprest system dengan demikian perusahaan dapat memanfaatkan catatan bank sebagai unsur pengendalian intern.

Dalam penerimaan dan pengeluaran kas Pusat Penelitian dan Pengembangan Peternakan menggunakan sistem komputerisasi sehingga hanya dokumen dasar yang digunakan yaitu jurnal transfer penerimaan dan pengeluaran kas. Jurnal ini digunakan oleh bagian kas untuk mencatat transaksi penerimaan dan pengeluaran kas secara manual yang nantinya dilaporkan ke bagian accounting untuk dilakukan penginputan data ke program komputer yang digunakan perusahaan.

Keywords : Sistem, Pengendalian Intern, Penerimaan Kas, Pengeluaran Kas. 


\section{KATA PENGANTAR}

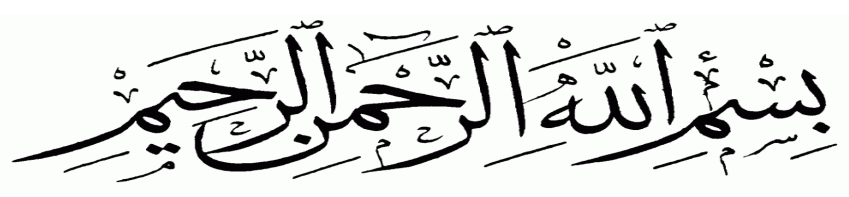

Assalamu'alaikum Wr. Wb.

Puji dan syukur penulis panjatkan kehadirat Allah SWT atas rahmat, karunia dan ridho-Nya, shalawat beserta salam semoga senantiasa terlimpah curahkan kepada nabi Muhammad SAW, kepada keluarganya, para sahabatnya, hingga kepada umatnya hingga akhir zaman, Amiin. Sehingga penulis dapat menyelesaikan Tugas Akhir dengan judul "Tinjauan Sistem Pengendalian Intern Terhadap Penerimaan dan Pengeluaran Kas pada Pusat Penelitian dan Pengembangan Peternakan".

Adapun maksud dan tujuan penyusunan Tugas Akhir ini adalah untuk memenuhi salah satu syarat memperoleh gelar/sarjana pada program Akuntansi Sekolah Tinggi Ilmu Ekonomi Kesatuan Bogor (Penelitian/Riset dilakukan pada Pusat Penelitian dan Pengembangan Peternakan Kementerian Pertanian, Jl. Raya Pajajaran Kav. E 59 Bogor).

Dalam penyusunan dan penulisan Tugas Akhir ini penulis banyak mendapat bantuan, bimbingan, dan arahan dari semua pihak. Maka dalam kesempatan ini penulis dengan segala hormat dan kerendahan hati dalam palung hati yang paling dalam menyampaikan terima kasih kepada semua pihak, diantaranya:

1. Kepada Allah SWT yang telah memberikan kemudahan dan kesehatan kepada penulis, sehingga penulis dapat menyelesaikan Tugas Akhir ini.

2. Kepada Kedua orangtua yang senantiasa selalu memberikan doa dan dukungannya baik dari segi moril maupun materiil.

3. Kakak dan adik, serta keponakan penulis yang telah memberikan dukungan dan doanya dalam menyelesaikan Tugas Akhir ini.

4. Bapak Nusa Muktiadji, Ir., MM selaku Ketua Sekolah Tinggi Ilmu Ekonomi Kesatuan Bogor yang memberi kesempatan kepada penulis untuk menyelesaikan pendidikan.

5. Ibu Yayuk Nurjanah, SE., M.,Ak selaku Ketua Program Studi Akuntansi Sekolah Tinggi Ilmu Ekonomi Kesatuan Bogor yang telah membantu penulis dalam berbagai hal.

6. Ibu Rini Yuli Prihatin, SE., M.,Ak selaku Pembimbing penulis yang telah dengan sabar meluangkan waktunya untuk memberikan masukan dan arahan kepada penulis.

7. Seluruh dosen Sekolah Tinggi Ilmu Ekonomi Kesatuan Bogor. 
8. Kepada Kepala Puslitbang Peternakan Bogor beserta staff jajarannya yang telah banyak membimbing dan mengarahkan penulis dalam menjalani setiap kegiatan selama ini.

9. Kepada seluruh staff perpustakaan yang telah membantu penulis dalam peminjaman buku-buku.

10. Rekan-rekan mahasiswa/i D3 Akuntansi Karyawan yang telah banyak membantu dalam memberikan dorongan dan semangat kepada penulis.

11. Semua pihak yang tidak mungkin penulis sebutkan satu persatu yang telah terlibat banyak membantu sehingga Tugas Akhir ini dapat diselesaikan.

Dalam penyusunan Tugas Akhir ini, penulis menyadari masih terdapat banyak kekurangan yang dibuat baik sengaja maupun tidak sengaja, dikarenakan keterbatasan ilmu pengetahuan dan wawasan serta pengalaman yang penulis miliki. Untuk itu penulis mohon maaf atas segala kekurangan tersebut tidak menutup diri untuk menerima kritik dan saran yang membangun kearah pengembangan kesempurnaan dari Tugas Akhir ini. Semoga Tugas Akhir ini dapat bermanfaat khususnya bagi pembelajaran di STIE Kesatuan Bogor.

Wassalamu'alaikum Wr.Wb.

Bogor, 30 September 2015

Penulis, 


\section{DAFTAR ISI}

Hal

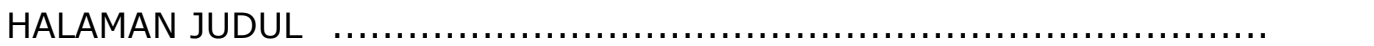

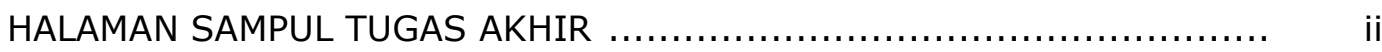

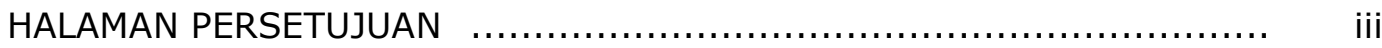

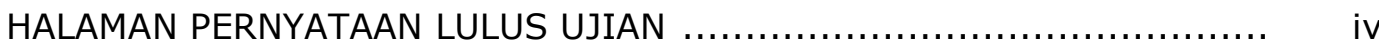

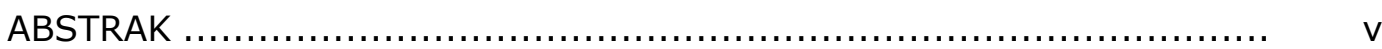

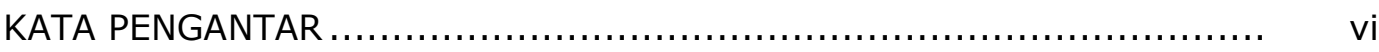

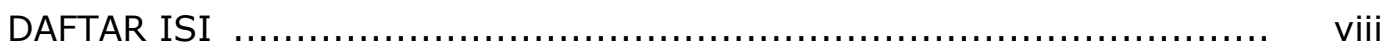

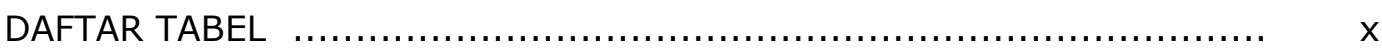

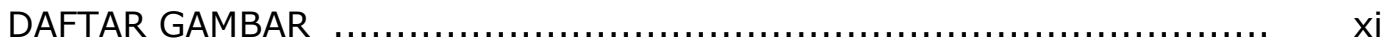

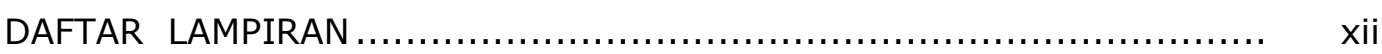

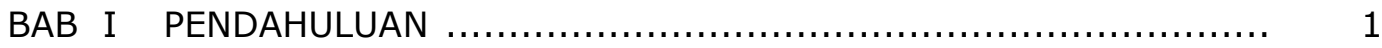

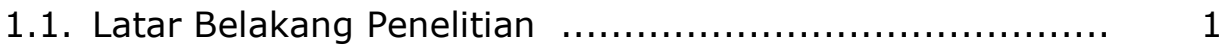

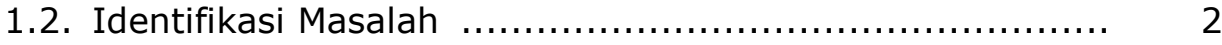

1.3. Maksud dan Tujuan .......................................... 3

1.4. Waktu dan Tempat Praktek Kerja .......................... 3

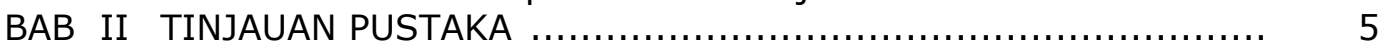

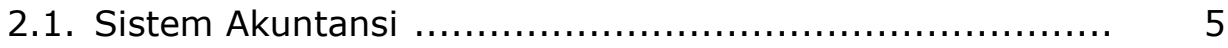

2.1.1. Pengertian Sistem dan Prosedur ..................... 5

2.1.2. Pengertian Sistem Akuntansi......................... 6

2.1.3. Karakteristik Sistem Akuntansi $\quad \ldots \ldots \ldots \ldots \ldots \ldots \ldots . \ldots . \ldots . \ldots 6$

2.2. Sistem Informasi Akuntansi ................................. 7

2.2.1. Pengertian Sistem Informasi Akuntansi .............. 7

2.2.2. Fungsi Utama Sistem Informasi Akuntansi............. 8

2.2.3. Tujuan Sistem Informasi Akuntansi................... 8

2.2.4. Karakteristik Sistem Informasi Akuntansi............. 8

2.3. Pengendalian Intern ....................................... 10

2.3.1. Pengertian Pengendalian Intern ........................ 10

2.3.2. Tujuan Pengendalian Intern ......................... 11

2.3.3. Unsur Pengendalian Intern ........................... 11

2.4. Sistem Akuntansi Penerimaan Kas ............................ 11

2.4.1. Sistem dan Prosedur Penerimaan Kas ............... 12

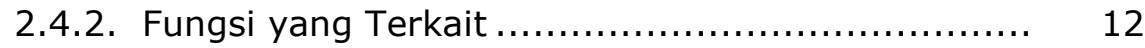

2.4.3. Catatan Akuntansi dan Dokumen yang Digunakan. 12

2.4.4. Laporan yang Dihasilkan ............................ 13

2.4.5. Uraian Prosedur .................................. 14

2.5. Sistem Akuntansi Pengeluaran Kas .......................... 14 
2.5.1. Sistem dan Prosedur Pengeluaran Kas .............. 15

2.5.2. Fungsi yang Terkait ............................. 16

2.5.3. Catatan Akuntansi dan Dokumen yang Digunakan. 16

2.5.4. Laporan yang Dihasilkan ........................... 17

2.5.5. Uraian Prosedur .................................. 17

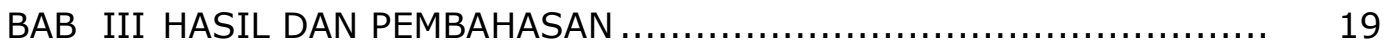

3.1 Sejarah Umum Perusahaan ............................... 19

3.1.1. Visi dan Misi Perusahaan ............................ $\quad 20$

3.1.2. Kegiatan Perusahaan ............................... $\quad 20$

3.2 Struktur organisasi dan Uraian Tugas....................... 21

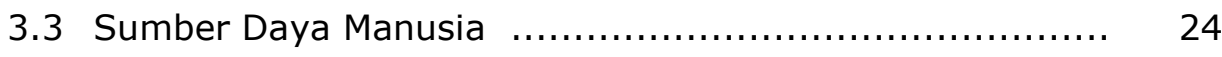

3.4 Sarana dan Prasarana .................................... $\quad 25$

3.5 Uraian Singkat Kegiatan Magang .......................... 27

3.6 Perbandingan Teori dan Praktek ................................ 28

3.6.1. Penerimaan Kas Tersedianya Anggaran Pemerintah 28

3.6.2. Catatan Akuntansi dan Dokumen yang Digunakan. 29

3.6.3. Prosedur Penerimaan Kas Puslitbangnak ............ $\quad 30$

3.6.4. Fungsi-Fungsi yang Terkait....................... 33

3.6.5. Catatan Akuntansi dan Dokumen yang Digunakan. 33

3.6.6. Prosedur Pengeluaran Kas Puslitbangnak............ 34

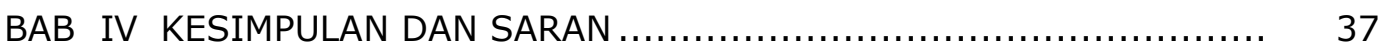

4.1. Kesimpulan ............................................. 37

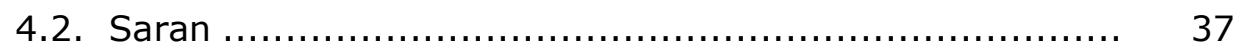

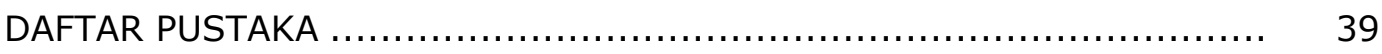

LAMPIRAN 


\section{DAFTAR TABEL}

No.

Teks

3.1. Daftar Sumber Daya Manusia Jabatan Fungsional Puslitbang Peternakan

3.2. Daftar Sumber Daya Manusia Tingkat Pendidikan Puslitbang Peternakan 


\section{DAFTAR GAMBAR}

No.

Teks

Hal

3.1. Struktur Organisasi Puslitbang Peternakan ......................... 22

3.2. Alur Prosedur Penerimaan Kas Puslitbang Peternakan ............... 31

3.3. Alur Prosedur Pengeluaran Kas Puslitbang Peternakan ............. 35 


\section{DAFTAR LAMPIRAN}

No.

Teks

$\mathrm{Hal}$

1. Buku Kas Umum Bank Puslitbang Peternakan ......................... 41

2. Buku Kas Umum Tunai Puslitbang Peternakan ........................ 42

3. Daftar Kehadiran Magang ............................................... 45

4. Laporan Kegiatan Aktifitas Magang .................................. 47

5. Nilai Evaluasi Magang ................................................ 57

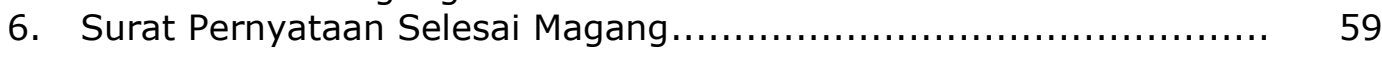




\section{BAB I \\ PENDAHULUAN}

\subsection{Latar Belakang}

Perkembangan ilmu pengetahuan dan teknologi mendorong manusia untuk hidup secara lebih praktis dan mudah, segala kemudahan ingin dicapai untuk dapat menemukan kepuasan pada setiap tindakan dalam segala bidang. Salah satu diantaranya muncul yang dinamakan sistem. Sistem adalah sekelompok unsur yang erat hubungan satu dengan yang lainnya, sehingga dengan ada sistem dan prosedur tersebut tujuan perusahaan dapat tercapai (Mulyadi, 2008).

Berdasarkan pernyataan tersebut Sistem Informasi Akuntansi (SIA) merupakan salah satu jenis sistem yang diperlukan oleh perusahaan dalam menangani kegiatan operasional sehari-hari untuk menghasilkan informasi-informasi akuntansi yang diperlukan oleh manajemen dan pihak-pihak terkait lainnya sehubungan dengan pengambilan keputusan dan kebijakan-kebijakan lainnya seperti halnya dalam melakukan penerimaan dan pengeluaran kas harus memiliki sistem dan prosedur sesuai dengan peraturan yang ada. Sebuah sistem pencatatan akuntansi akan lebih membantu jika dapat diaplikasikan dalam basis komputerisasi karena perkembangan teknologi yang paling nyata adalah pengembangan aplikasi teknologi komputer.

Informasi merupakan salah satu faktor yang penting bagi perusahaan dalam menjalankan kegiatannya, dimana terdapat pihak internal dan pihak eksternal yang juga memberi pengaruh dalam pemberian maupun penerimaan informasi terkait penerimaan dan pengeluaran kas. Berdasarkan pernyataan diatas, dapat dilihat suatu laporan atau pencatatan keuangan sangat penting bagi perusahaan.

Dengan semakin berkembangnya perusahaan maka fungsi pengendalian kurang dapat dilaksanakan dengan baik, karena jangkauan yang akan dikendalikan semakin luas dan kompleks, sehingga kemampuan manajemen dirasakan sangat terbatas, untuk itu manajemen memerlukan suatu alat yang dapat membantu menunjang dan meningkatkan fungsi pengendalian yang disebut pengendalian intern. Pengendalian intern merupakan suatu teknik pengawasan yaitu pengawasan keseluruhan dari kegiatan operasi perusahaan, baik mengenai organisasinya maupun sistem atau cara-cara yang digunakan untuk menjalankan perusahaan dan juga alat-alat yang digunakan perusahaan. Adapun pengendalian yang baik tidak menjamin tidak akan terjadi kesalahan dan penyelewengan dalam perusahaan, pengendalian yang memadai dimana dapat membantu manajemen menjaga keamanan hak milik perusahaan, dapat dipercayai datanya dan catatan akuntansi, menjamin dipatuhinya kebijakan perusahaan serta menunjang efisiensi perusahaan, pengendalian internal diperlukan dalam semua 
bidang yang ada dalam perusahaan, terutama sekali pengendalian internal kas.

Sistem pengendalian intern penerimaan dan pengeluaran kas yang baik juga harus diterapkan pada perusahaan maupun instansi atau badan. Hal ini dilakukan supaya tidak terjadi penyalahgunaan dana dari penerimaan dan pengeluaran kas, karena masih ada berkurangnya fungsi dalam pemeriksaan intern yang bertanggungjawab dalam melakukan perhitungan kas secara periodik dan mencocokkan hasil perhitungan dengan saldo kas menurut tatanan akuntansi serta melakukan pemeriksaan mendadak terhadap saldo kas yang ada ditangan.

Dalam pengendalian intern sistem penerimaan dan pengeluaran kas diperlukan adanya prosedur yang baik yang sesuai dengan kebijakan manajemen yang telah ditetapkan. Penerimaan dan pengeluaran kas yang dilakukan diluar prosedur yang telah ditentukan, akan memungkinkan terjadinya penyelewengan ataupun penggelapan kas maupun penerimaan dan pengeluaran kas yang tidak berfungsi pada fungsi jabatan terkait.

Dengan demikian jelaslah bahwa pengendalian intern tidak hanya memeriksa kebenaran angka-angka dan melindungi kekayaan perusahaan dari segi pembukuan dan pencatatan saja, tetapi juga memperhatikan struktur organisasi perusahaan, meningkatkan efisiensi kerja dan menganalisis seberapa jauh pelaksanaan kebijakan pimpinan yang telah digariskan oleh perusahaan telah dilaksanakan dengan baik.

Suatu pengendalian intern harus selalu dimonitor dan dievaluasi agar manfaat pengendalian intern tersebut senantiasa dapat dipertanggungjawabkan dan diketahui keabsahannya.

Dengan latar belakang tersebut maka penulis tertarik untuk mengambil judul penulisan Tugas Akhir ini yaitu : "Tinjauan Sistem Pengendalian Intern Terhadap Penerimaan dan Pengeluaran Kas pada Pusat Penelitian dan Pengembangan Peternakan Kota Bogor."

\subsection{Identifikasi Masalah}

Berdasarkan dari latar belakang yang telah dikemukakan di atas, maka penyusun mencoba untuk mengidentifikasi masalah yang akan dibahas dalam penelitian ini yaitu sebagai berikut:

1. Bagaimana penerapan sistem pengendalian intern terhadap penerimaan kas pada Puslitbang Peternakan?

2. Bagaimana penerapan sistem pengendalian intern terhadap pengeluaran kas pada Puslitbang Peternakan? 


\subsection{Maksud dan Tujuan}

Maksud peninjauan yang dilakukan penulis adalah sebagai berikut:

1. Untuk mengetahui sistem pengendalian intern terhadap penerimaan kas yang diterapkan pada Puslitbang Peternakan?

2. Untuk mengetahui sistem pengendalian intern terhadap pengeluaran kas yang diterapkan pada Puslitbang Peternakan?

Ada beberapa hal yang menjadi tujuan dari peninjauan ini, antara lain:

1. Untuk menggambarkan secara singkat tentang Sistem Penerimaan Kas pada Puslitbang Peternakan.

2. Untuk menggambarkan secara singkat tentang Sistem Pengeluaran Kas pada Puslitbang Peternakan.

\subsection{Tempat dan Waktu Penelitian}

Dalam melakukan kegiatan penulis mendapatkan kesempatan peninjauan yang dilaksanakan pada Pusat Penelitian dan Pengembangan Peternakan yang berada di Jl. Raya Padjajaran Kav. E 59 Bogor. Waktu pelaksanaan magang penulis lakukan dari pukul 07.30 WIB sampai dengan 16.00 dan waktu istirahat selama 1 jam pada pukul 12.00 sampai dengan 13.00 dilaksanakan selama 2 bulan, terhitung semenjak tanggal 6 April- 6 Juni 2015. 


\section{BAB II}

\section{TINJAUAN PUSTAKA}

\subsection{Sistem Akuntansi}

\subsubsection{Pengertian Sistem dan Prosedur}

Setiap perusahaan dalam melaksanakan kegiatannya akan melibatkan semua unsur-unsur yang ada dalam perusahaan itu, untuk berpartisipasi, agar apa yang telah direncanakan semula dapat berjalan sebagaimana mestinya dan mencapai tujuan tertentu. Oleh karena itu, sebuah perusahaan sangat membutuhkan suatu sistem dan prosedur dimana sistem ini sangat beraneka ragam. Sistem dan prosedur akan berjalan dengan baik apabila setiap karyawan yang menjalankannya dapat melaksanakan dengan baik dan teratur.

Sebelum membahas lebih lanjut mengenai sistem dan prosedur, ada baiknya kita mengetahui tentang definisinya. Adapun definisi dari sistem sebagai berikut:

Definisi sistem menurut Richard F.Neuchel dalam bukunya yang berjudul Management by System, "Sistem adalah suatu jaringan sejumlah prosedur yang saling berhubungan yang dikembangkan sesuai dengan suatu pola (rencana) guna melaksanakan aktivitas utama perusahaan". Adapun menurut Sutarman $(2009,5)$ menyatakan bahwa, "Sistem adalah kumpulan elemen yang saling berhubungan dan saling berinteraksi dalam satu kesatuan untuk menjalankan suatu proses pencapaian suatu tujuan utama. Sedangkan pengertian sistem menurut James A. Hall dalam bukunya Accounting Information System (2007) memberikan pengertian bahwa, "Sistem adalah memunculkan gambaran mental mengenai berbagai komputer dan pemrograman".

Sedangkan pengertian prosedur menurut Mulyadi $(2008,5)$ mengemukakan bahwa :

\footnotetext{
Suatu prosedur adalah suatu urutan-urutan pekerjaan klerikal, biasanya melibatkan beberapa orang dalam suatu departemen atau lebih, yang dibuat untuk menjamin penanganan secara seragam terhadap adanya transaksi-transaksi perusahaan yang terjadi berulang-ulang.
}

Dari manapun berbagai sumber atau referensi yang banyak dikemukakan oleh para ahli pada dasarnya "Sistem merupakan kelompok kedua atau lebih komponen atau subsistem yang saling berhubungan yang berfungsi dengan tujuan yang sama". 
Dari definisi di atas, dapat disimpulkan bahwa sistem adalah kumpulan atau rangkaian komponen-komponen yang saling berhubungan dan bekerja sama untuk mencapai suatu tujuan.

\subsubsection{Pengertian Sistem Akuntansi}

Sistem Akuntansi menurut Mulyadi $(2008,3)$ "Sistem Akuntansi adalah formulir, catatan, dan laporan yang dikoordinasi sedemikian rupa, untuk menyediakan informasi keuangan yang dibutuhkan oleh manajemen guna menjalankan pengelolaan perusahaan".

Menurut DRS. Narko, M.M. AKT $(2007,3)$ Sistem akuntansi pada umumnya diartikan sebagai jaringan yang terdiri dari formulir-formulir, catatan-catatan, prosedurprosedur, alat-alat dan sumber daya manusia dalam rangka menghasilkan informasi pada suatu organisasi untuk keperluan pengawasan operasi maupun untuk kepentingan pengambilan keputusan bisnis bagi pihak-pihak yang berkepentingan.

\subsubsection{Karakteristik Sistem Akuntansi}

Adapun karakteristik sistem akuntansi menurut Raymond Mc. Leod, Jr yang diterjemahkan oleh Hendra Teguh, SE, Ak mengatakan bahwa ada 5 karakteristik sistem akuntansi, diantaranya:

1. Melaksanakan tugas yang diperlukan.

Perusahaan diharuskan menjalankan pengelolaan data memelihara catatancatatannya yang diperlukan oleh berbagai pihak seperti pemerintah, pemegang saham dan pegawai itu sendiri. Peraturan dan praktek yang diterima, menentukan cara pelaksanaan pengolahan data segala jenis organisasi dalam mengolah datanya dengan cara yang sama.

2. Menangani data yang rinci.

Karena berbagai pengolahan data menjelaskan kegiatan perusahaan secara rinci, catatan tersebut yang menyediakan jejak audit. Jejak audit adalah kronologi kegiatan yang dapat ditelusuri dari awal hingga akhir dan sebaliknya.

3. Terutama berfokus pada histories.

Data yang dikumpulkan oleh sistem informasi akuntansi adalah data yang dikumpulkan pada masa lampau.

4. Menyediakan informasi pemecahan masalah minimal, SIA menghasilkan sebahagian output bagi manajer perusahaan. 


\subsection{Sistem Informasi Akuntansi}

\subsubsection{Pengertian Sistem Informasi Akuntansi}

Informasi Akuntansi adalah data yang telah dikelola dan diproses untuk memberikan arti dan memperbaiki proses pengambilan keputusan. Kelebihan informasi adalah ketika terjadinya batasan tersebut yang dilewati, mengakibatkan penurunan kualitas dalam pengambilan keputusan dan meningkatkan biaya penyediaan informasi.

Sebagaimana definisi yang disampaikan di atas, kita dapat mendefinisikan Sistem Informasi Akuntansi sebagai sistem berbasis komputer yang dirancang untuk mengubah data akuntansi menjadi informasi. Namun demikian, menggunakan istilah sistem informasi akuntansi secara lebih luas, yaitu mencakup siklus pemrosesan transaksi, penggunaan teknologi informasi, dan pengembangan sistem informasi.

Menurut Kieso Sistem Informasi Akuntansi adalah "The System of collecting and processing transaction and disseminating financial information to interest parties". Definisi menurut Stephen A. Moscove dan Mark G. Simkin: "SIA adalah suatu komponen organisasi yang mengumpulkan, mengklasifikasikan, memproses, menganalisis, mengkomunikasikan informasi pengambilan keputusan dengan orientasi financial yang relevan bagi pihak-pihak luar dan pihak-pihak dalam perusahaan". Adapun Menurut George H. Bodnar dan William S. Hopwood "Sistem Informasi Akuntansi merupakan kumpulan sumber daya, seperti manusia dan peralatan, yang dirancang untuk mengubah data keuangan dari data lainnya ke dalam informasi".

SIA sangat efektif dan penting bagi keberhasilan jangka panjang organisasi manapun. Tanpa perangkat untuk mengawasi aktivitas-aktivitas yang terjadi, tidak akan ada cara untuk memutuskan seberapa baik kinerja perusahaan. Setiap organisasi juga perlu menelusuri pengaruh-pengaruh berbagai aktivitas atas sumber daya yang berada dibawah pengawasannya. Informasi tentang para pelaku yang terlibat dalam aktivitasaktivitas tersebut penting untuk menetapkan tanggungjawab dari tindakan yang diambil.

Menurut Marshall B. Romney didalam bukunya yang berjudul Accounting Information System (2006) mengatakan bahwa "Sistem Informasi Akuntansi adalah sekumpulan dari lima komponen yang secara bersama-sama bertujuan memungkinkan suatu SIA dapat memenuhi dalam tiga fungsi penting didalam berorganisasi". Adapun lima komponen yang terdiri dalam SIA menurut Marshall B. Romney adalah:

1. Orang-orang yang dapat mengoperasikan sistem tersebut dan melaksanakan berbagai fungsi.

2. Prosedur-prosedur, baik manual maupun yang terotomatisasi, yang dilibatkan dalam mengumpulkan, memproses, dan menyimpan data tentang aktivitas-aktivitas organisasi.

3. Data tentang proses-proses bisnis organisasi. 
4. Software yang di pakai untuk memproses data organisasi.

5. Infrastruktur teknologi informasi, termasuk komputer, peralatan pendukung (peripheral device), dan peralatan untuk komunikasi jaringan.

\subsubsection{Fungsi Utama Sistem Informasi Akuntansi}

Adapun fungsi utama dari sistem informasi akuntansi menurut Mulyadi adalah sebagai berikut:

1. Mengumpulkan dan menyimpan data dari semua aktivitas dan transaksi perusahaan.

2. Memproses data menjadi informasi yang berguna dalam pengambilan keputusan yang memungkinkan bagi pihak manajemen untuk melakukan perencanaan.

3. Menyediakan kontrol yang cukup untuk menjaga aset dari organisasi termasuk data. Kontrol ini juga memastikan bahwa data akan tersedia ketika dibutuhkan dan data tersebut akurat serta dapat dipercaya.

\subsubsection{Tujuan Sistem Informasi Akuntansi}

Sedangkan Tujuan umum pengembangan Sistem Akuntansi dalam bukunya Mulyadi $(2008,19)$ yang berjudul Sistem Akuntansi mempunyai tujuan sebagai berikut:

1. Untuk mengurangi biaya klerikal dalam penyelenggaraan catatan akuntansi, dalam hal ini informasi dapat disajikan sebagai barang ekonomi yang mempunyai banyak manfaat.

2. Untuk memperbaiki pengendalian akuntansi dan pengecekan internal, untuk memperbaiki tingkat keandalan (reliability) informasi akuntansi dan menyediakan catatan lengkap mengenai pertanggungjawaban kekayaan perusahaan.

3. Untuk menyediakan informasi bagi pengelolaan kegiatan usaha baru, dalam perusahaan yang baru berjalan sangat dibutuhkan pengembangan sistem akuntansi.

4. Untuk meningkatkan informasi yang baru berjalan yang dihasilkan oleh sistem yang sudah ada, sering kali sistem akuntansi yang berlaku tidak dapat memenuhi kebutuhan manajemen dan ketepatan penyajian struktur informasi yang terdapat dalam laporan.

\subsubsection{Karakteristik Sistem Informasi Akuntansi}

Sistem informasi akuntansi akan memberikan manfaat bagi para pemakainya, baik dalam maupun luar lingkungan perusahaan apabila memiliki karakteristik tertentu. Sebagaimana dikemukakan oleh Barry E. Cushing dalam bukunya Accounting 
Information System and Business Organization yang diterjemahkan oleh Ruchyat Kosasih adalah sebagai berikut:

1. Usefullness.

Suatu sistem dapat menghasilkan informasi yang tepat waktu dan relevan dengan pengambilan keputusan yang dibuat manajemen serta pelaksanaan operasi pegawai.

2. Economy.

Seluruh bagian dari sistem termasuk laporan, pengendalian, serta alat-alat memberikan kontribusi nilai keuntungan lebih besar dari biaya yang dikeluarkan.

3. Reliability.

Hasil dari sistem informasi tersebut mempunyai tingkat kegunaan yang tinggi. Dan sistem dapat beroperasi secara efektif, bahkan pada saat alat-alat mesin dalam suatu waktu tidak dapat digunakan.

4. Customer Service.

Sistem informasi harus dapat memberikan pelayanan dengan baik dan efisien kepada para pelanggan.

5. Capacity.

Kapasitas dari sistem harus cukup untuk menangani saat dimana aktivitas operasi mengalami kenaikan.

6. Simplicity.

Suatu system dirancang cukup sederhana, sehingga struktur operasinya dapat dengan mudah dimengerti serta prosedurnya mudah dilaksanakan.

7. Flexibility.

Suatu sistem harus flexibel dalam menghadapi perubahan yang terjadi sebagai adanya kondisi yang berubah ataupun keperluan- lain organisasi.

Adapun karakteristik Informasi yang berguna adalah sebagai berikut:

1. Relevan, mengurangi ketidakpastian, meningkatkan pengambilankeputusan, serta menegaskan atau memperbaiki ekspektasi sebelumnya.

2. Reliabel, bebas dari kesalahan atau bias, menyajikan kejadian atau aktivitas organisasi secara akurat.

3. Lengkap, tidak menghilangkan aspek penting dari suatu kejadian atau aktivitas yang diukur.

4. Tepat waktu, diberikan pada waktu yang tepat bagi pengambil keputusan dalam mengambil keputusan.

5. Dapat dipahami, disajikan dalam format yang dapat dimengerti dan jelas.

6. Dapat diverifikasi dua orang yang independen, dan berpengetahuan dibidangnya, dan masing-masing menghasilkan informasi yang sama. 
7. Dapat diakses, tersedia untuk pengguna ketika mereka membutuhkannya dan dalam format yang dapat digunakan.

\title{
2.3 Pengendalian Intern
}

\subsubsection{Pengertian Pengendalian Intern.}

Pengendalian Intern sangat penting bagi kelangsungan kegiatan perusahaan. Tanpa pengendalian intern yang baik bisa menyebabkan perusahaan tidak memperoleh laba yang optimal bahkan bisa menyebabkan perusahaan gulung tikar.

Pengertian Pengendalian Intern dalam bukunya "Accounting" yang diterjemahkan oleh Aria Farahmita dkk, adalah:

\begin{abstract}
Pengendalian Internal (Internal Control) adalah kebijakan dua prosedur yang melindungi aktiva perusahaan dari kesalahan penggunaan, memastikan bahwa informasi usaha yang disajikan akurat dan meyakinkan bahwa hukum serta peraturan telah diikuti. (Warren Reeve Fees, 2005:235).
\end{abstract}

Sedangkan Pengertian pengendalian intern menurut American Institute of Certified Public Accountant (AICPA) didefinisikan sebagai pengawasan intern, dimana:

\begin{abstract}
Pengawasan Intern meliputi struktur organisasi, semua metode dan pengukuran yang terkoordinasi dalam suatu perusahaan, untuk melindungi aktiva, menjaga ketelitian dan keterpercayaan data akuntansi, meningkatkan efisiensi dan mendorong dipatuhinya kebijaksanaan manajemen. (Wing Wahyu Winarno, 2005:88).
\end{abstract}

Dari pengertian di atas dapat diuraikan bahwa manajemen bertanggungjawab menyiapkan laporan keuangan untuk investor, kreditor dan para pemakai lainnya baik secara hukum maupun profesionalnya untuk meyakinkan bahwa informasi disajikan secara benar, jujur dan dapat dipercaya. Pengendalian dalam suatu organisasi bertujuan untuk mendorong penggunaan sumber dayanya termasuk pegawai secara efektif dan efisien untuk mengoptimalkan tujuan organisasi. 


\subsubsection{Tujuan Pengendalian Intern}

Menurut AICPA, Pengendalian Intern meliputi struktur organisasi dan semua caracara serta alat-alat yang dikoordinasikan digunakan dalam perusahaan dengan tujuan untuk menjaga keamanan harta milik perusahaan, memeriksa ketelitian dan kebenaran data akuntansi, memajukan efisiensi didalam usaha, dan membantu mendorong dipatuhinya kebijakan manajemen yang telah ditetapkan lebih dahulu.

Definisi di atas menunjukkan bahwa suatu sistem pengendalian intern yang baik itu akan berguna untuk:

1. Menjaga keamanan harta milik suatu organisasi.

2. Memeriksa ketelitian dan kebenaran data akuntansi.

3. Memajukan efisiensi dalam operasi.

4. Membantu menjaga agar tidak ada yang menyimpang dari kebijakan manajemen yang telah ditetapkan terlebih dahulu.

\subsubsection{Unsur Pengendalian Intern}

Adapun unsur-unsur pengendalian intern menurut Mulyadi dalam bukunya yang berjudul Sistem Akuntansi adalah sebagai berikut:

1. Fungsi penyimpanan kas harus terpisah dari fungsi akuntansi.

2. Transaksi penerimaan dan pengeluaran kas tidak boleh dilaksanakan sendiri oleh bagian kas sejak awal sampai akhir tanpa campur tangan dari fungsi yang lain.

3. Pengeluaran kas harus mendapat otorisasi dari pejabat yang tercantum.

4. Pembukuan dan penutupan rekening bank harus mendapatkan persetujuan dari pejabat yang berwewenang.

5. Pencatatan dalam jurnal pengeluaran kas.

\subsection{Sistem Akuntansi Penerimaan Kas}

Pengertian Penerimaan Kas menurut PSAK no. 9, definisi kas adalah alat pembayaran yang bebas dan siap dipergunakan untuk membiayai kegiatan umum perusahaan. Penerimaan kas adalah sejumlah uang yang masuk dan tercatat dalam kas perusahaan atau dalam rekening bank yang merupakan hasil dari kegiatan penjualan atau dari hasil penerimaan piutang tertagih. Kas adalah alat pembayaran yang siap dan bebas digunakan untuk membiayai kegiatan umum perusahaan. Rekening bank adalah saldo rekening giro perusahaan yang dapat dipergunakan secara bebas untuk membiayai kegiatan umum perusahaan. 
Menurut Stice dan Skousen ( 2005 : 495 ) mendefinisikan kas adalah "Aktiva lancar yang paling likuid dan terdiri dari bagian yang bertindak sebagai alat pertukaran serta memberikan dasar untuk perhitungan akuntansi".

Penerimaan kas perusahaan berasal dari dua sumber utama, yaitu penerimaan dan penjualan tunai dan penerimaan kas dari piutang atau dari penjualan secara kredit. Di bawah ini akan dibahas mengenai kedua sistem akuntansi penerimaan kas tersebut.

\subsubsection{Sistem dan Prosedur Penerimaan Kas}

Sumber dari penerimaan kas suatu instansi atau perusahaan publik atau pemerintahan, umumnya berasal dari 2 sumber yaitu:

\section{a. Sistem Penerimaan Kas dari Tersedianya Anggaran Kas dari Pemerintah}

Sistem penerimaan kas yang ada pada instansi atau perusahaan pada pemerintahan umumnya didapat dari tersedianya anggaran kas dari pemerintah. Adapun dana anggaran kas yang diperoleh berasal dari pemerintah, dan diberlakukan setiap tahunnya. Prosedur akuntansi penerimaan kas meliputi serangkaian proses, baik manual maupun secara terkomputerisasi, mulai dari pencatatan, penggolongan, dan peringkasan transaksi dan/atau atas kejadian atau peristiwa yang terjadi terhadap keuangan, hingga pelaporan keuangan dalam rangka pertanggungjawaban pelaksanaan APBD yang berkaitan dengan penerimaan kas pada SKPD dan/atau SKPKD.

\subsubsection{Fungsi yang Terkait}

Adapun fungsi-fungsi yang terkait dalam prosedur akuntansi penerimaan kas adalah yaitu pada SKPD yang dilaksanakan oleh fungsi akuntansi pada PPK-SKPD, sedangkan pada SKPKD dilaksanakan oleh fungsi akuntansi pada SKPKD.

\subsubsection{Catatan Akuntansi atau Dokumen yang Digunakan}

Adapun catatan akuntansi atau dokumen yang digunakan dalam prosedur penerimaan kas pada SKPD dan/atau SKPKD adalah terdiri atas:

a. Surat Ketetapan Pajak Daerah (SKPD), digunakan untuk menetapkan pajak daerah atas wajib pajak yang dibuat oleh PPKD.

b. Surat Ketetapan Retribusi Daerah (SKRD), digunakan untuk menetapkan retribusi daerah atas wajib retribusi yang dibuat oleh pengguna anggaran. 
c. Surat Tanda Bukti Penerimaan (STBP), digunakan untuk mencatat setiap penerimaan pembayaran dari pihak ketiga yang diselenggarakan oleh bendahara penerimaan.

d. Surat Tanda Setoran (STS), digunakan untuk menyetorkan penerimaan daerah yang diselenggarakan oleh bendahara penerimaan pada SKPD.

e. Bukti Transfer, merupakan dokumen atau bukti atas transfer penerimaan daerah.

f. Nota kredit bank, merupakan dokumen atau bukti dari bank yang menunjukkan adanya transfer uang masuk ke rekening kas.

g. Buku jurnal penerimaan kas, merupakan catatan yang diselenggarakan oleh fungsi akuntansi untuk mencatat dan menggolongkan semua transaksi atau kejadian yang berhubungan dengan penerimaan kas.

h. Buku besar, merupakan catatan yang diselenggarakan oleh fungsi akuntansi untuk memosting semua transaksi atau kejadian selain kas dari jurnal penerimaan kas ke buku besar untuk setiap rekening aset, kewajiban, ekuitas dana, pendapatan, belanja, dan pembiayaan.

i. Buku Besar Pembantu, merupakan catatan yang diselenggarakan oleh fungsi akuntansi untuk mencatat semua transaksi atau kejadian yang berisi rincian akun buku besar untuk setiap rekening yang dianggap perlu.

\subsubsection{Laporan yang Dihasilkan}

Adapun jenis laporan yang dihasilkan dalam prosedur akuntansi penerimaan kas pada SKPD terdiri atas:

a) Laporan yang dihasilkan dalam prosedur akuntansi penerimaan kas pada SKPD terdiri atas:

1. Laporan realisasi anggaran (LRA)

2. Neraca

3. Catatan Atas Laporan Keuangan (CALK)

b) Laporan yang dihasilkan dalam prosedur akuntansi penerimaan kas pada SKPKD terdiri atas:

1. Laporan realisasi Anggaran (LRA)

2. Neraca

3. Laporan Arus Kas

4. Catatan Atas Laporan Keuangan (CALK) 


\subsubsection{Uraian Prosedur}

a. Prosedur akuntansi penerimaan kas pada SKPD dilaksanakan oleh fungsi akuntansi pada PPK-SKPD, sedangkan pada SKPKD dilaksanakan oleh fungsi akuntansi pada SKPKD.

b. Fungsi akuntansi pada PPK-SKPD berdasarkan bukti transaksi penerimaan kas melakukan pencatatan ke dalam jurnal penerimaan kas, disertai rekening-lawan asal penerimaan kas tersebut.

c. Bukti transaksi penerimaan kas mencakup antara lain:

1) Surat Tanda Bukti Pembayaran (STBP)

2) Surat Tanda Setoran (STS)

3) Bukti Transfer

4) Nota kredit

5) Bukti penerimaan lainnya

d. Fungsi akuntansi pada PPK-SKPD dan/atau fungsi akuntansi pada SKPKD secara periodik atau berkala melakukan posting ke buku besar.

e. Jika dianggap perlu, fungsi akuntansi pada PPK-SKPD dan/atau fungsi akuntansi pada SKPKD dapat membuat buku besar pembantu yang berfungsi sebagai rincian buku besar dan berlaku sebagai kontrol.

f. Pencatatan ke dalam jurnal penerimaan kas, buku besar, dan buku besar pembantu dilaksanakan oleh fungsi akuntansi pada PPK-SKPD dan/atau fungsi akuntansi pada SKPKD sesuai dengan tugas pokok dan fungsi yang telah ditetapkan dalam ketentuan yang berlaku.

g. Pada akhir periode, fungsi akuntansi pada PPK-SKPD dan/atau fungsi akuntansi pada SKPKD menyusun laporan keuangan.

\subsection{Sistem Akuntansi Pengeluaran Kas}

Didalam perusahaan, pengeluaran kas merupakan suatu transaksi yang sering terjadi. Dana-dana yang dikeluarkan perusahaan misalnya digunakan untuk biaya pemeliharaan, biaya upah/gaji pegawai, biaya perlengkapan dan peralatan dan pengeluaran lainnya. Menurut James A. Hall yang diterjemahkan oleh Amir Abadi Jusuf dalam buku yang berjudul Sistem Informasi Akuntansi menyatakan definisi pengeluaran kas bahwa: "Sistem pengeluaran kas adalah memproses pembayaran kewajiban yang dihasilkan oleh sistem pembelian". 


\title{
2.5.1 Sistem dan Prosedur Pengeluaran Kas
}

Secara garis besar pengeluaran kas perusahaan dilakukan melalui dua sistem, yaitu sistem pengeluaran kas dengan cek dan sistem pengeluaran kas dengan uang tunai melalui dana kas kecil. Pengeluaran kas yang dilakukan dengan tunai biasanya karena jumlahnya relatif kecil.

\begin{abstract}
Pembayaran kas dalam perusahaan dilakukan dengan menggunakan cek kecuali untuk pembayaran dalam kecil, biasanya dilaksanakan melalui dana kas kecil. Dana kas kecil merupakan uang kas yang disediakan untuk membayar pengeluaran-pengeluaran yang jumlahnya relatif kecil dan tidak ekonomis apabila dibayar dengan cek. (Zaki Baridwan, 2005:63).
\end{abstract}

Menurut Baridwan $(2009,187)$ menambahkan, "Prosedur pengeluaran kas adalah prosedur pengeluaran cek untuk melunasi utang yang sudah disetujui dan mencatat pengeluaran kas, serta pengeluaran-pengeluaran lain yang berhubungan dengan kegiatan operasional perusahaan".

Pengeluaran kas dengan cek dinilai lebih aman dibanding dengan pengeluaran kas secara tunai. Adapun kebaikan pengeluaran kas melalui cek ditinjau dari pengendalian internnya, sebagai berikut:

1. Dengan menggunakan cek atas nama, pengeluaran cek akan diterima oleh pihak yang namanya tertulis dalam formulir cek.

2. Dengan menggunakan cek, pencatatan transaksi pengeluaran kas juga akan terekam oleh pihak bank.

3. Jika sistem perbankan mengembalikan cancelled check sebagai tanda check issuer, pengeluaran kas dengan cek memberi manfaat tambahan bagi perusahaan dengan dapat digunakannya chancelled check sebagai tanda terima kas dari pihak yang menerima pembayaran.

Seperti halnya penerimaan kas, sistem pengeluaran kas juga memiliki prosedur yang dirancang sedemikian rupa sehingga terhindar dari pencurian, kehilangan kas ataupun pengeluaran-pengeluaran yang tidak tepat pengalokasiannya, sehingga hanya pengeluaran-pengeluaran yang telah disetujui dan benar-benar untuk kegiatan perusahaan saja yang dicatat dalam pembukuan perusahaan.

Dari uraian di atas, maka dapat disimpulkan bahwa pengeluaran kas adalah suatu transaksi yang menimbulkan berkurangnya saldo-saldo kas tunai milik perusahaan baik yang digunakan untuk aktivitas pembelian persediaan perusahaan, pembayaran hutang dagang, maupun beban-beban yang mendukung aktivitas operasional perusahaan yang menyebabkan berkurangnya kas milik perusahaan. 
Prosedur akuntansi peengeluaran kas meliputi serangkaian proses, baik manual maupun terkomputerisasi, mulai dari pencatatan, penggolongan, dan peringkasan transaksi dan/atau kejadian keuangan, hingga pelaporan keuangan dalam rangka pertanggungjawaban pelaksanaan APBD yang berkaitan dengan pengeluaran kas pada SKPD dan/atau SKPKD.

\subsubsection{Fungsi yang Terkait}

Adapun fungsi terkait yang digunakan dalam prosedur pengeluaran kas pada SKPD dilaksanakan oleh fungsi akuntansi pada PPK-SKPD, sedangkan pada SKPKD dilaksanakan oleh fungsi akuntansi pada SKPKD.

\subsubsection{Catatan Akuntansi atau Dokumen yang Digunakan}

Catatan akuntansi atau Dokumen yang digunakan dalam prosedur akuntansi pengeluaran kas pada SKPD dan/atau SKPKD terdiri atas:

1. Surat Penyediaan Dana (SPD), merupakan dokumen yang dibuat oleh Pejabat Pengelola Keuangan Daerah (PPKD) sebagai media atau surat yang menunjukkan tersedianya dana untuk diserap/direalisasi.

2. Surat Perintah Membayar (SPM), merupakan dokumen yang dibuat oleh pengguna anggaran untuk mengajukan Surat Perintah Pencairan Dana (SP2D) yang akan diterbitkan oleh Bendahara Umum Daerah (BUD) atau Kuasa BUD.

3. Kuitansi pembayaran dan bukti pembayaran lainnya, merupakan dokumen sebagai tanda bukti pembayaran.

4. SP2D, merupakan dokumen yang diterbitkan oleh BUD atau Kuasa BUD untuk mencairkan uang pada bank yang telah ditunjuk.

5. Bukti Transfer, merupakan dokumen atau bukti atas transfer pengeluaran daerah.

6. Nota debit bank, merupakan dokumen atas bukti dari bank yang menunjukkan adanya transfer uang keluar dari rekening kas umum daerah.

7. Buku jurnal pengeluaran kas, merupakan catatan yang diselenggarakan oleh fungsi akuntansi untuk mencatat dan menggolongkan semua transaksi atau kejadian yang berhubungan dengan pengeluaran kas.

8. Buku besar, merupakan catatan yang diselenggarakan oleh fungsi akuntansi untuk memosting semua transaksi atau kejadian selain kas dari jurnal pengeluaran kas ke buku besar untuk setiap rekening aset, kewajiban, ekuitas dana, pendapatan, belanja dan pembiayaan. 
9. Buku besar pembantu, merupakan catatan yang diselenggarakan oleh fungsi akuntansi untuk mencatat semua transaksi atau kejadian yang berisi rincian akun buku besar untuk setiap rekening yang dianggap perlu.

\subsubsection{Laporan yang Dihasilkan}

Adapun laporan yang dihasilkan dalam prosedur akuntansi pengeluaran kas pada SKPD terdiri atas:

1. Laporan realisasi anggaran (LRA)

2. Neraca

3. Catatan Atas Laporan Keuangan (CALK)

Dan adapun laporan yang dihasilkan dalam prosedur akuntansi pengeluaran kas pada SKPKD terdiri atas:

1. Laporan Realisasi Anggaran (LRA)

2. Neraca

3. Laporan Arus Kas

4. Catatan Atas Laporan Keuangan (CALK)

\subsubsection{Uraian Prosedur}

Adapun uraian prosedur akuntansi pengeluaran kas pada SKPD adalah:

1. Prosedur akuntansi pengeluaran kas pada SKPD dilaksanakan oleh fungsi akuntansi pada PPK-SKPD, sedangkan pada SKPKD dilaksanakan oleh fungsi akuntansi pada SKPKD.

2. Fungsi akuntansi pada PPK-SKPD berdasarkan bukti transaksi pengeluaran kas melakukan pencatatan ke dalam jurnal pengeluaran kas, disertai rekening lawan asal pengeluaran kas tersebut.

3. Bukti transaksi pengeluaran kas mencakup antara lain:
a. SP2D
b. Bukti Transfer
c. Nota kredit
d. Bukti penerimaan lainnya

4. Fungsi akuntansi pada PPK-SKPD dan/atau fungsi akuntansi pada SKPKD secara periodik atau berkala melakukan posting ke buku besar.

5. Jika dianggap perlu, fungsi akuntansi pada PPK-SKPD dan/atau fungsi akuntansi pada SPKPD dapat membuat buku besar pembantu yang berfungsi sebagai rincian buku besar dan berlaku sebagai kontrol. 
6. Pencatatan ke dalam jurnal pengeluaran kas, buku besar, dan buku besar pembantu dilaksanakan oleh fungsi akuntansi pada PPK-SKPD dan/atau fungsi akuntansi pada SKPKD sesuai dengan tugas pokok dan fungsi yang telah ditetapkan dalam ketentuan yang berlaku.

7. Pada akhir periode, fungsi akuntansi pada PPK-SKPD dan/atau fungsi akuntansi pada SKPKD menyusun laporan keuangan.

Adapun fungsi yang terkait didalam pengeluaran kas adalah sebagai berikut:

1. Fungsi yang Memerlukan Pengeluaran Kas.

Apabila suatu fungsi memerlukan pengeluaran kas, maka fungsi tersebut mengajukan permintaan cek kepada fungsi pencatat utang.

2. Fungsi Pencatat Utang.

Fungsi ini bertanggungjawab atas pembuatan bukti kas keluar yang memberikan otorisasi kepada fungsi keuangan dalam mengeluarkan cek sebesar yang tercantum dalam dokumen tersebut. Fungsi ini juga bertanggungjawab untuk melakukan verifikasi kelengkapan dan validitas dokumen pendukung yang dipakai sebagai dasar pembuatan bukti kas keluar. Selain ini juga fungsi ini juga bertanggungjawab untuk menyelenggarakan arsip bukti kas keluar yang belum dibayar yang berfungsi sebagai buku pembantu.

3. Fungsi Keuangan.

Fungsi ini bertanggungjawab untuk mengisi cek, memintakan otorisasi atas cek dan mengirimkan cek kepada kreditur via pos atau membayarkan langsung kepada kreditur.

4. Fungsi Akuntansi Biaya.

Fungsi ini bertanggungjawab atas pencatatan pengeluaran kas yang menyangkut biaya dan persediaan.

5. Fungsi Akuntansi Umum.

Fungsi ini bertanggungjawab atas pencatatan transaksi pengeluaran kas dalam jurnal pengeluaran kas atau register.

6. Fungsi Audit Intern.

Fungsi ini bertanggungjawab untuk melakukan perhitungan kas secara periodik dan mencocokkan hasil perhitungannya dengan saldo kas menurut catatan akuntansi. Selain itu juga bertanggungjawab melakukan pemeriksaan secara mendadak terhadap saldo kas yang ada ditangan dan membuat rekonsiliasi bank secara periodik. 


\section{BAB III \\ HASIL DAN PEMBAHASAN}

\subsection{Sejarah Umum Perusahaan}

Pusat Penelitian dan Pengembangan Peternakan (Puslitbangnak) merupakan salah satu Unit Kerja (UK) eselon II yang berada dibawah Kementerian Pertanian (KEMENTAN). Sebagai salah satu lembaga penelitian dibawah koordinasi dan bertanggungjawab langsung kepada Badan Penelitian dan Pengembangan Pertanian (Balitbangtan). Puslitbangnak melaksanakan tugas dan fungsinya sesuai Peraturan Menteri Pertanian Nomor: 61/Permentan/OT.140/10/2010 tentang Organisasi dan Tata Kerja Kementerian Pertanian. Puslitbangnak dalam melakukan tugasnya didukung oleh empat Unit Pelaksana Teknis (UPT) yaitu Balai Besar Penelitian Veteriner (BBLitvet) di Bogor, Balai Penelitian Ternak (Balitnak) di Ciawi, Loka Penelitian Kambing Potong (Lolitkapo) di Grati-Pasuruan, dan Loka Penelitian Sapi Potong (Lolitsapo) di Sei. PutihMedan.

Puslitbangnak bersama keempat UPT-nya memberikan pelayanan dalam bentuk fisik dan jasa berupa: Publikasi hasil penelitian, Pelayanan konsultasi, Pelayanan penelitian, Magang budidaya, Kesehatan hewan, Pelayanan uji diagnostik, Penyakit hewan, Pengujian (obat hewan, vaksin, disinvektan, antimikroba, dII) serta Menyediakan ruang seminar dan perlengkapannya juga menyediakan fasilitas untuk penginapan.

Keberadaan Puslitbangnak sebagai lembaga penelitian nasional memiliki peran strategis, terutama dalam mendukung program Kementan yang berkaitan dengan bidang peternakan. Salah satu peran penting Puslitbangnak adalah melaksanakan program untuk mendukung swasembada daging sapi. Program tersebut sejalan dengan Visi Kementan dalam menciptakan ketahanan pangan. Selain itu, Puslitbangnak juga dituntut dapat berperan lebih besar dalam mengantisipasi dinamika perubahan lingkungan, serta berperan nyata dalam pembangunan peternakan.

Puslitbangnak dinilai mampu menjalankan mandat penelitian dan pengembangan di Bidang Peternakan dan Veteriner. Mandat tersebut merupakan tugas strategis dalam upaya mendukung program pemerintah khususnya Program Swasembada Daging Sapi dan Kerbau 2015 (PSDSK 2015).

Puslitbangnak mempunyai tugas pokok melaksanakan koordinasi penelitian teknologi tinggi dan strategi pengembangan inovasi teknologi peternakan dan veteriner, Puslitbangnak mempunyai fungsi dalam: 
1. Perumusan program penelitian dan pengembangan teknologi tinggi peternakan dan veteriner.

2. Pemberian pelayanan penelitian dan pengembangan teknologi peternakan dan veteriner.

3. Evaluasi pelaksanaan penelitian, dan

4. Pelaksanaan urusan Rumah Tangga dan Tata Usaha Pusat (RT dan TUP).

\subsubsection{Visi dan Misi Perusahaan}

Visi

Menjadikan lembaga penelitian dan pengembangan peternakan bertaraf internasional yang menghasilkan dan mengembangkan inovasi teknologi untuk mewujudkan peternakan unggul, berkelanjutan dan berbasis sumber daya lokal

Misi

1) Memanfaatkan Sumber Daya Genetik (SDG) lokal secara berkelanjutan untuk menghasilkan bibit/benih/seed vaksin/mikroba unggul, untuk mewujudkan peternakan yang berdaya saing dan berkelanjutan.

2) Merakit dan mengembangkan teknologi inovatif peternakan dan veteriner mendukung peternakan berkelanjutan.

3) Menghasilkan rekomendasi kebijakan peternakan dan veteriner sesuai dengan dinamika dan perkembangan lingkungan strategis.

4) Meningkatkan kerjasama penelitian dan pengembangan dengan lembaga terkait ditingkat nasional dan internasional.

5) Menghasilkan publikasi ilmiah bertaraf nasional dan internasional, melaksanakan diseminasi hasil penelitian dan menjaring umpan balik teknologi peternakan dan veteriner.

6) Meningkatkan kapasitas sumber daya penelitian secara efektif dan efisien.

\subsubsection{Kegiatan Perusahan}

Kegiatan utama perusahaan adalah di Bidang Penelitian dan Pengembangan Peternakan, melaksanakan koordinasi penelitian teknologi tinggi dan strategi pengembangan inovasi teknologi peternakan dan veteriner.

Adapun publikasi/produk yang dihasilkan pada Puslitbangnak diantaranya adalah:

1. JITV (Jurnal IImu Ternak dan Veteriner)

2. Wartazoa

3. KUB/Note KUB 
4. Prosiding Semnas (Seminar Nasional)

5. Lokakarya nasional

6. Booklet peternakan dan veteriner

7. Repository perpustakaan digital

8. OJS (Open Journal System)

\subsection{Struktur Organisasi Perusahaan}

Guna mencapai tujuan yang diharapkan, maka dibutuhkan organisasi yang baik dan terencana. Organisasi adalah salah satu alat bagi instansi unit kerja dan koordinasi suatu perusahaan dalam mencapai tujuannya. Organisasi itu sendiri merupakan bentuk perserikatan atau kerjasama antar manusia. Untuk melaksanakan tugas, maka Pusat Penelitian dan Pengembangan Peternakan (Puslitbangnak) telah menentukan tugas dan fungsi dari masing-masing bagian.

Didalam unit kerja dan koordinasi instansi perusahaan, struktur organisasi merupakan salah satu unsur dari pengendalian intern yang baik yaitu adanya suatu pemisahan tanggung jawab, sehingga dapat terciptanya suatu koordinasi maupun komunikasi yang tepat dan terarah antara pimpinan dan bawahan dalam melaksanakan tugas atau pekerjaan. Selain itu pembagian tugas, wewenang dan tanggung jawab yang jelas akan sangat mendukung sekali dalam pencapaian tujuan organisasi yang baik dalam aktivitas pengelolanya.

Struktur organisasi yang ada pada Pusat Penelitian dan Pengembangan Peternakan, tentunya akan sangat berbeda dengan struktur organisasi di instansi atau unit kerja koordinasi perusahaan lain. Hal ini dapat disebabkan oleh adanya kebijaksanaan manajemen atau dari dalam unit kerja dan koordinasi instansi perusahaan tersebut. Adapun struktur organisasi unit kerja dan koordinasi Pusat Penelitian dan Pengembangan Peternakan dapat dilihat di bawah ini. 


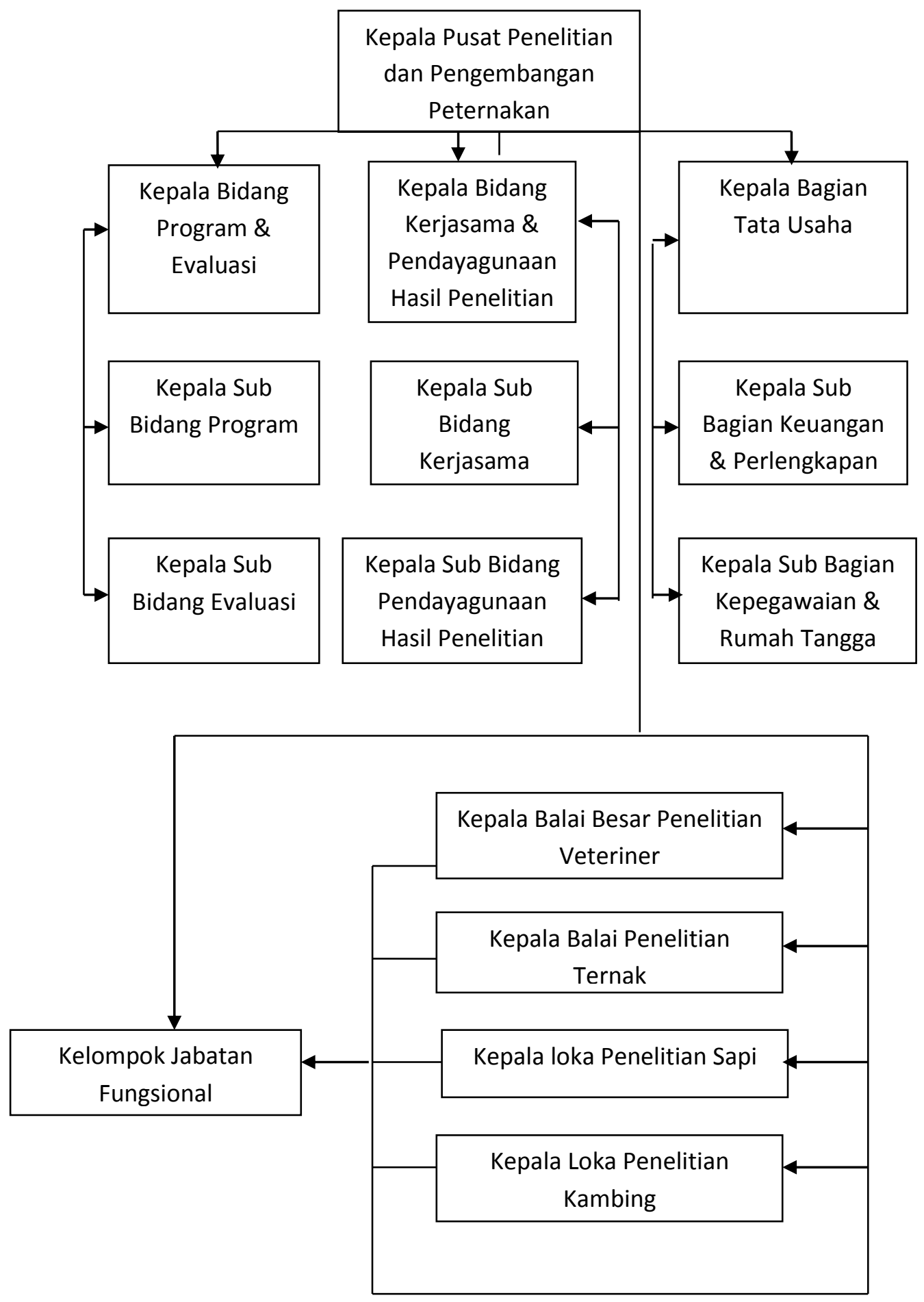

Gambar 3.1

Struktur Organisasi Pusat Penelitian dan Pengembangan Peternakan 


\section{Uraian Tugas}

Di bawah ini akan dijelaskan uraian tugas kerja dalam struktur organisasi satuan unit kerja dan koordinasi Pusat Penelitian dan Pengembangan Peternakan beserta tugas dan fungsinya masing-masing.

1. Kepala Pusat

Kepala Pusat (Kapus) ini mempunyai hak dan andil pengambilan keputusan yang paling tinggi dan berpengaruh dalam satuan unit kerja dan koordinasi instansi perusahaan, memiliki kekuasaan penuh dalam segala upaya kebijakan keputusan bagi kelangsungan aktivitas pengendalian pengelolaan, penelitian dan pengembangan serta memiliki wewenang koordinasi langsung kepada semua bagian untuk menyampaikan kebijakan-kebijakan dan tugas serta pengarahan.

2. Kepala Bidang Program dan Evaluasi

Kepala Bidang Program dan Evaluasi (Kabid. ProEva) ini mempunyai hak pengambilan keputusan dalam bidang pemrograman dan mengkoordinasi suatu aktivitas pengendalian pengelolaan maupun evaluasi didalam bidangnya, serta memiliki wewenang koordinasi langsung kepada semua bawahan atau staff-nya untuk mengelola aktivitas pada sub-sub bidangnya.

3. Kepala Bidang Kerjasama dan Pendayagunaan Hasil Penelitian Kepala Bidang Kerjasama dan Pendayagunaan Hasil Penelitian (Kabid. Kerdahaslit) ini mempunyai hak pengambilan keputusan dalam bidang bidang kerjasama dan pendayagunaan hasil penelitian suatu pengendalian pengelolaan didalam bidangnya, menjalin kerjasama dan membudidayakan hasil penelitian, serta memiliki wewenang koordinasi langsung kepada semua bawahan atau stafnya untuk mengelola aktivitas pada sub-sub bidangnya.

4. Kepala Bagian Tata Usaha

Kepala Bagian Tata Usaha (Kabag. TU) ini mempunyai hak pengambilan keputusan dalam bagian pengelolaan tata usaha, serta memiliki wewenang koordinasi langsung kepada semua bawahan atau staf-nya untuk mengelola aktivitas pada sub-sub bidangnya.

5. Kepala Bagian Keuangan dan Perlengkapan

Kepala Bagian Keuangan dan Perlengkapan (Kabag. KeuKap) ini mempunyai hak pengambilan keputusan dalam bagian pengelolaan keuangan, pengelolaan kas serta anggaran dan bagian perlengkapan juga peralatan yang tergabung dalam satu sub unit kerja, serta memiliki wewenang koordinasi langsung kepada semua bawahan atau staf-nya untuk mengelola aktivitas pada sub-sub bidang pengelolaannya. 
Bagian Accounting bertugas dalam:

a) Mengawasi pelaksanaan prosedur keuangan.

b) Mengadakan pengawasan terhadap realisasi anggaran perusahaan yang sedang berjalan.

c) Memeriksa kebenaran dan kelengkapan seluruh pencatatan transaksi keuangan perusahaan.

d) Mengontrol tagihan dan kas masuk.

6. Kepala Bagian Kepegawaian dan Rumah Tangga

Kepala Bagian Kepegawaian dan Rumah Tangga (Kabag. Peg-RT) ini mempunyai hak pengambilan keputusan dalam bagian sistem kepegawaian dan staff yang tergabung dalam satu sub unit kerja, serta memiliki wewenang koordinasi langsung kepada semua bawahan atau staff-nya untuk mengelola aktivitas pada sub-sub bidang pengelolaannya.

\subsection{Sumber Daya Manusia}

Mengetahui bahwa Sumber Daya Manusia (SDM) adalah kunci yang terpenting dalam keberhasilan suatu organisasi, maka Puslitbangnak mengkonsentrasikan pada pengembangan sumber daya manusia sebagai "aset" termahal yang harus dikembangkan.

Dalam satuan unit kerja dan koordinasi perusahaan ini Sumber Daya Manusia sudah cukup baik. Sumber Daya Manusia pada Puslitbangnak yang berada di Bagian Pengelolaan, Penelitian dan Pengembangan berjumlah $x x x$ orang dengan jenjang pendidikan. Pendidikan Sumber Daya Manusia dalam satuan unit kerja dan koordinasi perusahaan ini cukup beragam, mulai dengan adanya berbagai tingkat pendidikan pegawai mulai dari setara SMA hingga S3.

Dalam menjalankan usahanya Puslitbangnak mempekerjakan beberapa orang karyawan yang ditempatkan dibeberapa bagian yang dapat bekerja sesuai fungsi dan tugasnya masing-masing antara lain: 
Tabel 3.1

Daftar Sumber Daya Manusia Pusat Penelitian dan Pengembangan Peternakan Tahun 2015

\begin{tabular}{|c|c|c|c|c|c|}
\hline \multirow{2}{*}{ No } & \multirow{2}{*}{ Satuan Kerja } & \multicolumn{3}{|c|}{ Jabatan Fungsional } & \multirow{2}{*}{ Jumlah } \\
\hline & & Arsiparis & Litkayasa & Humas & \\
\hline 1 & Puslitbangnak & 2 & 15 & 38 & 55 \\
\hline 2 & BBLitvet & 5 & 115 & 116 & 236 \\
\hline 3 & Balitnak & 3 & 122 & 137 & 262 \\
\hline 4 & Lolitsapi & - & 24 & 50 & 74 \\
\hline 5 & Lolitkambing & 1 & 15 & 28 & 44 \\
\hline & Jumlah & 11 & 291 & 369 & 671 \\
\hline
\end{tabular}

Tabel 3.2

Daftar Sumber Daya Manusia Pusat Penelitian dan Pengembangan Peternakan Tahun 2015

\begin{tabular}{|c|c|c|c|c|c|c|}
\hline \multirow{2}{*}{ No } & \multirow{2}{*}{ Satuan Kerja } & \multicolumn{4}{|c|}{ Tingkat Pendidikan } & \multirow{2}{*}{ Jumlah } \\
\cline { 3 - 6 } & & SLTA/Dipl & S1 & S2 & S3 & \\
\hline 1 & Puslitbangnak & 27 & 13 & 6 & 9 & 55 \\
\hline 2 & BBLitvet & 166 & 33 & 18 & 19 & 236 \\
\hline 3 & Balitnak & 188 & 25 & 22 & 27 & 262 \\
\hline 4 & Lolitsapi & 51 & 13 & 8 & 2 & 74 \\
\hline 5 & Lolitkambing & 28 & 4 & 9 & 3 & 44 \\
\hline & Jumlah & 460 & 88 & 63 & 60 & 671 \\
\hline
\end{tabular}

Sumber : Bagian Kepegawaian dan Arsiparis Pusat Penelitian dan Pengembangan Peternakan

\subsection{Sarana dan Prasarana}

Pusat Penelitian dan Pengembangan Peternakan berlokasi di Jalan Raya Pajajaran Kav. E 59, Bogor. Dalam melakukan aktifitas perusahaan, perusahaan ini pun memiliki berbagai macam sarana dan prasarana yang dapat mendukung aktifitas perusahaan tersebut. Dimana perusahaan ini memiliki gedung yang terbagi menjadi beberapa ruang, antara lain: 
1. Kantor

Sebagai ruang yang digunakan untuk semua staff dan para manajer perusahaan dalam melakukan aktifitas pekerjaannya.

2. Ruang Meeting / Rapat

Ruang yang difungsikan sebagai tempat untuk membahas suatu pekerjaan dengan para staff dan para manajer.

3. Ruang Aula Pertemuan

Sebagai ruang yang digunakan untuk mengadakan pertemuan dengan para staff dan manajer dari luar daerah dalam melakukan kunjungan maupun melakukan aktifitas pekerjaannya.

4. Mess penginapan

Mess atau ruang penginapan yang disediakan oleh perusahaan untuk para peserta Litbang (Penelitian dan Pengembangan) yang datang dari luar daerah yang akan melakukan penelitian maupun pengembangan di perusahaan tersebut.

5. Halaman Tengah Gedung Utama

6. Halaman Samping Kiri dan Kanan

7. Perpustakaan / Gallery

8. Musholla

9. Tempat Parkir

10. Pos Satpam

Prasarana untuk mendukung dalam melaksanakan kegiatan Penerimaan dan Pengeluaran Kas pada Pusat Penelitian dan Pengembangan Peternakan adalah sebagai berikut:

1. Komputer

2. Printer

3. Mesin scan

4. Mesin fotocopy

5. Mesin fax

6. Mesin tik

7. Meja kerja

8. Kursi kantor

9. Mobil untuk melakukan penelitian

10. Mobil untuk mengantar peserta Litbang

11. Jaringan Wifi

12. Lemari arsip / dokumen

13. Lemari brankas

14. AC 
15. Mesin penyimpan uang kas

16. Kulkas

17. Televisi

18. Telepon

\subsection{Uraian Singkat Kegiatan Magang}

Saat penulis diberikan kesempatan melakukan penelitian riset/magang di Perusahaan tersebut, penulis ditempatkan pada Bagian Staff Keuangan. Adapun serangkaian kegiatan pekerjaan yang penulis lakukan diantaranya adalah sebagai berikut:

1. Menginput data pengeluaran kas perusahaan.

Adapun tugas saya selama melakukan kegiatan magang yakni salah satunya Menginput data pengeluaran kas perusahaan. Seperti Menginput data perjalanan dinas pegawai, Membuat daftar perhitungan uang makan, Mencatat gaji induk untuk para pegawai dan Menginput data pembayaran Tunjangan Kinerja (Tukin) pegawai.

2. Menginput data rekapitulasi pertanggungjawaban perusahaan.

Adapun tugas saya yang kedua selama melakukan kegiatan magang yakni salah satunya Menginput data rekapitulasi pertanggungjawaban. Seperti Menginput data rekapitulasi pertanggungjawaban kuitansi, Menginput data pertanggungjawaban anggaran dengan menggunakan aplikasi RKAKL (Rencana Kegiatan Anggaran Kementerian dan Lembaga), Menginput data konfirmasi penerimaan negara pada Puslitbang Peternakan.

3. Menginput data penerimaan Perusahaan.

Adapun tugas saya yang ketiga selama melakukan kegiatan magang yakni salah satunya yaitu Menginput data penerimaan perusahaan. Seperti Menginput data anggaran penerimaan kas perusahaan, Merekapitulasi data anggaran penerimaan kas perusahaan, Mencatat dan menginput data gaji yang akan diterima oleh pegawai setiap bulannya.

4. Mengklasifikasikan dan men-cap berkas DPA, perjalanan dinas dan kuitansi.

5. Menginput data Buku Kas Umum (BKU) ke dalam SPB.

Adapun tugas saya yang terakhir selama melakukan kegiatan magang yakni salah satunya yaitu Menginput data Buku Kas Umum (BKU). Buku Kas Umum adalah Buku atau catatan suatu perusahaan yang dapat dibuat dalam bentuk skontro, dengan sisi debit untuk mencatat penerimaan, dan sisi kredit untuk mencatat pengeluaran. 


\subsection{Perbandingan Teori dan Praktek}

\section{a. Penerapan Sistem Penerimaan Kas pada Pusat Penelitian dan Pengembangan Peternakan}

Pusat Penelitian dan Pengembangan Peternakan ini merupakan satuan unit kerja dan kesatuan koordinasi pemerintahan yang bergerak di bidang penelitian dan pengembangan di Badan Penelitian dan Pengembangan Pertanian. Sistem penerimaan kas yang digunakan pada Pusat Penelitian dan Pengembangan Peternakan diperoleh dari tersedianya anggaran tahunan dari pemerintah yang disetorkan secara tunai melalui bank (dengan cara transfer ke rekening perusahaan), untuk mendanai segala bentuk aktifitas kegiatan perusahaan, pembayaran gaji/pegawai perusahaan, untuk melengkapi segala sarana dan prasarana perusahaan, serta digunakan untuk membeli peralatan dan perlengkapan perusahaan. Dimana penerimaan kas itu sendiri nantinya dilakukan dengan proses dan prosedur serta memperlihatkan tanda bukti kegunaan anggaran yang sudah dipakai sebelumnya kepada pemerintah.

\subsubsection{Penerimaan Kas dari Tersedianya Anggaran Tahunan Pemerintah}

Informasi tentang sistem akuntansi penerimaan kas yang dibuat oleh Pusat Penelitian dan Pengembangan Peternakan berawal dari tersedianya anggaran tahunan dari pemerintah yang disetorkan secara tunai melalui bank yang ditransfer langsung kepada rekening perusahaan, untuk mendanai segala kegiatan aktifitas perusahaan. Sebelum anggaran tahunan dicairkan, anggaran dana yang akan digunakan untuk tahun berikutnya harus dibuat Perencanaan Kegiatan Anggaran pada Kementerian dan Lembaga (RKAKL).

Fungsi yang terkait dalam penerimaan kas dari tersedianya anggaran tahunan dari pemerintah antara lain :

1. Fungsi Keuangan

Fungsi ini bertanggungjawab untuk melakukan pencatatan manual kedalam form aplikasi permohonan permintaan anggaran dari pemerintah untuk penerimaan kas yang nantinya dari anggaran penerimaan kas itu bisa digunakan untuk segala keperluan dan kebutuhan aktifitas kegiatan perusahaan dan membayar gaji karyawan. Fungsi ini juga bertanggungjawab untuk menyetorkan kas yang diterima ke bank dan mengecek segala jenis pembayaran melalui transfer ke rekening perusahaan sesuai dengan surat pemberitahuan permohonan permintaan anggaran kas dan melakukan pelaporan ke Bagian Akuntansi. 
Fungsi ini bertanggungjawab dalam pencatatan perolehan penerimaan kas dari tersedianya anggaran tahunan dari pemerintah kedalam penerimaan kas yang ada pada program komputer perusahaan dengan data manual maupun aplikasi dari fungsi kas dan secara otomatis akan memperoleh format pertanggungjawaban serta siap melakukan prosedur penerimaan kas.

2. Fungsi Kas

Fungsi ini bertanggungjawab dalam pengelolaan dana kas masuk kepada rekening perusahaan. Fungsi ini juga bertanggung jawab atas penerimaan cek dari fungsi keuangan dan akuntansi. Fungsi kas juga bertanggungjawab untuk menyetorkan kas yang diterima dari berbagai fungsi tersebut dengan segera ke bank dalam jumlah penuh. Fungsi ini juga bertanggungjawab dalam melaksanakan penghitungan kas yang ada ditangan fungsi kas secara periodik. Selain itu juga bertanggung jawab dalam melakukan rekonsiliasi bank untuk mengecek ketelitian catatan kas yang diselenggarakan oleh fungsi akuntansi.

\subsubsection{Catatan Akuntansi dan Dokumen yang Digunakan}

Adapun dokumen yang digunakan oleh Pusat Penelitian dan Pengembangan Peternakan adalah sebagai berikut :

1. Bukti Penerimaan Kas Masuk

Dokumen ini digunakan sebagai bukti penerimaan uang yang masuk dari anggaran yang disediakan oleh pemerintah dengan rangkap 3, lembar atau form 1 digunakan untuk format pertanggungjawaban, lembar ke 2 ke Bagian Keuangan dan lembar 3 diberikan kepada Bagian Accounting untuk di arsip.

2. Form Pertanggungjawaban

Form pertanggungjawaban ini sebagai salah satu prosedur pengisian untuk Perencanaan Kegiatan Anggaran dari Kementerian dan Lembaga. Dimana form ini nantinya sebagai bukti dasar pengelolaan anggaran kas kegiatan proses aktifitas perusahaan, yang nantinya dapat dipertanggungjawabkan.

3. Form RKAKL (Rencana Kegiatan Anggaran Kementerian dan Lembaga)

Dokumen atau form ini adalah perencanaan dan penganggaran yang berisi program dan kegiatan suatu Kementerian Negara/Lembaga, yang merupakan penjabaran dari Rencana Kerja Pemerintah (RKP) dan Rencana Kerja Strategis Kementerian Negara/Lembaga (Renstra K/L), yang bersangkutan dalam satu tahun anggaran untuk menjadi pedoman pelaksanaan program dan kegiatan. Form ini nantinya akan berisikan Rencana Kegiatan Anggaran Kementerian dan Lembaga, segala proses dan prosedur yang direncanakan akan dijabarkan melalui form ini. 
Dalam memperoleh dan memproses anggaran penerimaan kas Pusat Penelitian dan Pengembangan Peternakan menggunakan sistem pencatatan secara komputerisasi dengan menggunakan Microsoft Excel dan Aplikasi yang dirancang sendiri oleh sistem Kementerian dan Lembaga. Seluruh transaksi dan input data, perencanaan pengelolaan data pada anggaran kas dan segala jenis pengeluaran menggunakan aplikasi khusus dan catatan dasar (manual).

\subsubsection{Prosedur Penerimaan Kas}

Adapun prosedur penerimaan kas Perencanaan Kegiatan Anggaran pada Pusat Penelitian dan Pengembangan Peternakan digambarkan dalam bagan sebagai berikut: 


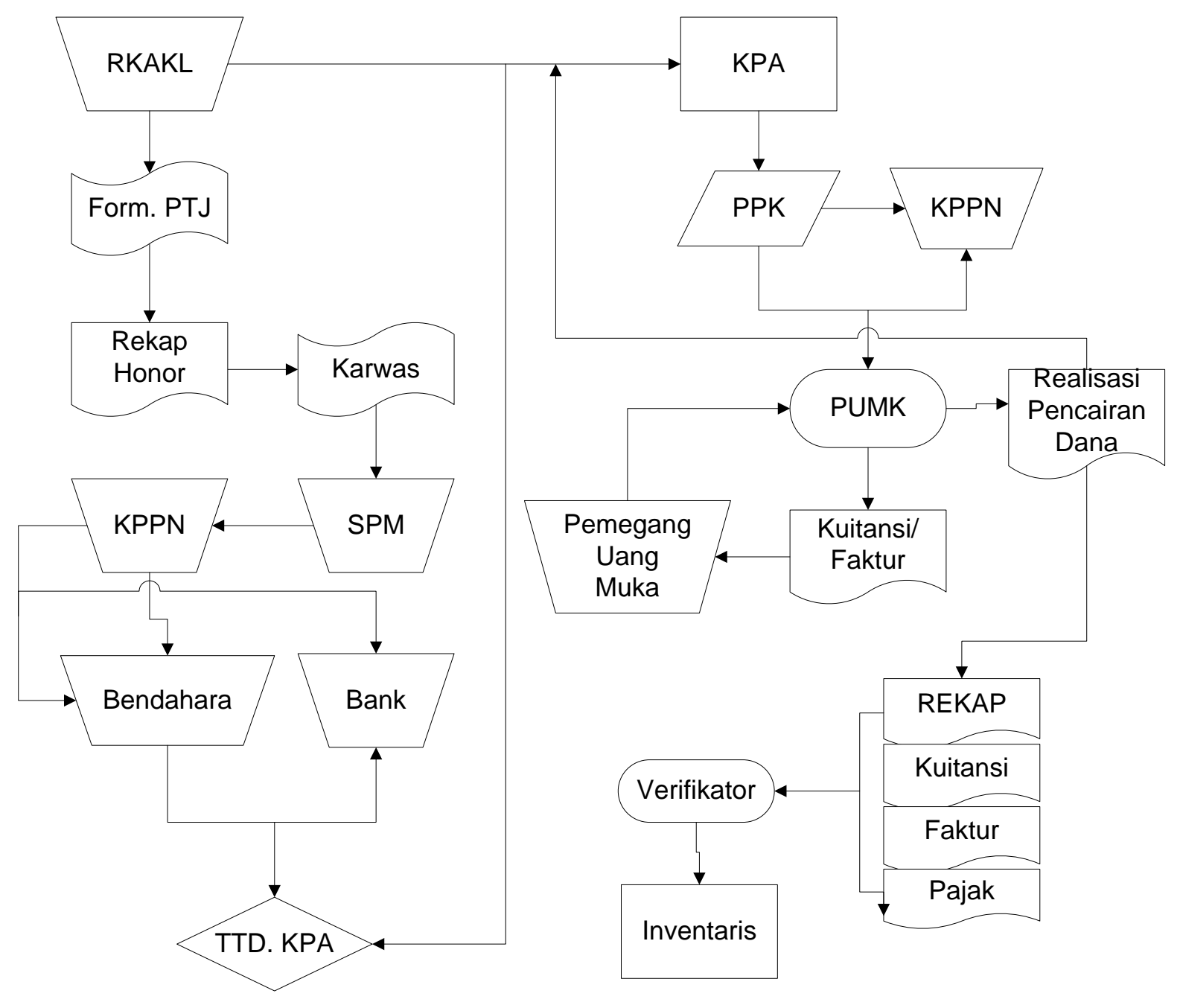

Gambar 3.2

Alur Prosedur Penerimaan Kas Pusat Penelitian dan Pengembangan Peternakan

Keterangan:

- RKAKL : Rencana Kegiatan Anggaran Kementerian dan Lembaga

- Form. PTJ : Formulir Pertanggungjawaban

- SPM : Surat Perintah Membayar

- KPPN : Kantor Pelayanan Pembendaharaan Negara

- KPA : Kuasa Pengguna Anggaran

- PPK : Pejabat Penatausahaan Keuangan

- PUMK : Pelaksana Umum Kegiatan 
Keterangan :

Rencana Kegiatan Anggaran Kementerian dan Lembaga (RKAKL) merupakan salah satu serangkaian prosedur permohonan permintaan penerimaan kas yang nantinya akan disediakan oleh pemerintah, yang fungsinya untuk menampung segala jenis perencanaan dan penganggaran yang akan berisi program dan kegiatan pada perusahaan untuk setahun kedepan. Setelah menyusun rencana kegiatan anggaran, maka dibentuklah format pertanggungjawaban yang dimana form ini sebagai salah satu prosedur pengisian untuk Perencanaan Kegiatan Anggaran dari Kementerian dan Lembaga. Dimana form ini nantinya sebagai bukti dasar pengelolaan anggaran kas kegiatan proses aktifitas perusahaan, yang nantinya dapat dipertanggungjawabkan. Setelah itu, didapatlah rekapitulasi honor kemudian di cross check. Setelah di cross check dilaporkan kepada Karwas (Kartu Pengawas) dan diinput ke dalam SPM dan dilaporkan ke KPPN, kemudian di cek lagi. Setelah benar pengisian dan prosedur semuanya kemudian di cek lagi ke Bagian Bendahara, nantinya dari Bendahara akan disetorkan lagi ke bank, dan dari bank akan di cek lagi sampai nantinya mendapat persetujuan dari KPA.

Setelah mendapatkan persetujuan dari KPA (Kuasa Pengguna Anggaran) Puslitbang Peternakan setiap pertengahan tahun harus menyiapkan format pertanggungjawaban RKAKL dan DPA (Daftar Pelaksanaan Anggaran). DPA pada dasarnya berisi semua perincian kas untuk melaksanakan kegiatan pada bulan berikutnya yang menyangkut anggaran yang sudah diterima dari tersedianya anggaran dari pemerintah.

Setelah RKAKL pertanggungjawaban mendapatkan persetujuan dari KPA (Kuasa Pengguna Anggaran), untuk selanjutnya diwewenangkan kepada PPK (Pejabat Penatausahaan Keuangan) anggaran, dan diperiksa lagi oleh KPPN (Kantor Pelayanan Pembendaharaan Negara) beserta lampiran honor karyawan, untuk kemudian diurus oleh PUMK (Pelaksana Umum Kegiatan). Dari PUMK diproses berdasarkan RKAKL (Rencana Kegiatan Anggaran Kementerian dan Lembaga) sebagai rencana kegiatan setahun kedepan atau proses uang muka untuk kemudian direalisasikan sebagai pencairan dana. Dalam proses pencairan dana harus melampirkan beberapa dokumen atau form atau pertanggungjawaban seperti rekapitulasi penggajian karyawan, kuitansi persediaan perusahaan, faktur persediaan dan pajak yang menjadi tanggungan serta hal-hal pertanggungjawaban yang terjadi didalam aktivitas perusahaan untuk kemudian didasari sebagai pencairan dana penerimaan kas. Selanjutnya di cross check oleh verifikator (pihak pengklasifikasian rencana kegiatan anggaran) untuk kemudian dilaporkan kepada 
penyelia persediaan (inventaris), sebagai salah satu wadah atau tempat dari salah satu perencanaan kegiatan yang akan digunakan untuk 1 tahun kedepan.

\section{b. Penerapan Sistem Pengeluaran Kas pada Pusat Penelitian dan Pengembangan Peternakan}

Dalam pengeluaran kas Pusat Penelitian dan Pengembangan Peternakan menggunakan sistem pengeluaran kas dengan menggunakan sistem pencatatan aplikasi dan juga secara manual apabila pengeluaran yang dilakukan dalam jumlah besar, sedangkan pengeluaran kas yang relatif kecil pembayaran biasanya menggunakan uang tunai dari tersedianya anggaran tahunan yang sudah ada.

\subsubsection{Fungsi-Fungsi yang Terkait dengan Sistem Pengeluaran Kas}

Adapun fungsi-fungsi yang terkait dengan sistem pengeluaran kas yang digunakan pada Pusat Penelitian dan Pengembangan Peternakan adalah sebagai berikut:

1. Bagian Accounting

Fungsi ini bertanggungjawab untuk menginput semua transaksi pengeluaran kas yang dilaporkan bagian kas kedalam program komputerisasi sehingga menghasilkan laporan keuangan yang nantinya akan dilaporkan ke pada pimpinan setiap satu bulan sekali.

2. Bagian Keuangan

Fungsi ini bertanggungjawab menyiapkan cek sekaligus menginput data untuk segala jenis pembayaran kas untuk membeli perlengkapan dan peralatan untuk kegiatan aktifitas operasional perusahaan.

\subsubsection{Catatan Akuntansi dan Dokumen yang Digunakan}

Adapun dokumen pengeluaran kas yang digunakan oleh Pusat Penelitian dan Pengembangan Peternakan adalah sebagai berikut:

1. Bukti Kas Keluar

Dokumen ini digunakan oleh bagian kas untuk melaporkan pengeluaran kas yang dilakukan ke principle ke pada Bagian Akuntansi.

2. Form Jurnal Pengeluaran Kas

Form ini biasanya digunakan oleh Bagian Kas untuk melaporkan pengeluaran kas baik secara tunai maupun melalui bank yang dicatat secara manual dan menjadi dokumen dasar dalam penginputan data ke dalam komputer. 


\section{Slip Gaji}

Dokumen ini digunakan sebagai bukti pembayaran gaji karyawan setiap bulannya oleh Bagian Kas.

4. Nota Kontan

Dokumen ini digunakan untuk pengeluaran-pengeluaran tunai perusahaan, misalnya untuk pembelian perlengkapan dan peralatan dan lain-lain.

5. Surat Perjalanan Dinas

Form ini sangat penting digunakan oleh pegawai yang akan melakukan perjalanan dinas ke luar kota maupun dalam melakukan perjalanan yang ada hubungannya dengan kegiatan perusahaan.

Dalam mencatat transaksi pengeluaran kas Pusat Penelitian dan Pengembangan Peternakan menggunakan sistem pencatatan secara komputerisasi dengan Microsoft Excel. Jadi hanya catatan dasar yang digunakan yaitu formulir jurnal, pengeluaran kas yang dicatat secara manual oleh Bagian Kas. Kemudian dari data-data tersebut baru akan diinput pengeluaran kas secara komputerisasi oleh Bagian Akuntansi.

\subsubsection{Prosedur Pengeluaran Kas}

Prosedur pengeluaran kas pada Pusat Penelitian dan Pengembangan Peternakan dapat dilihat pada gambar berikut ini : 


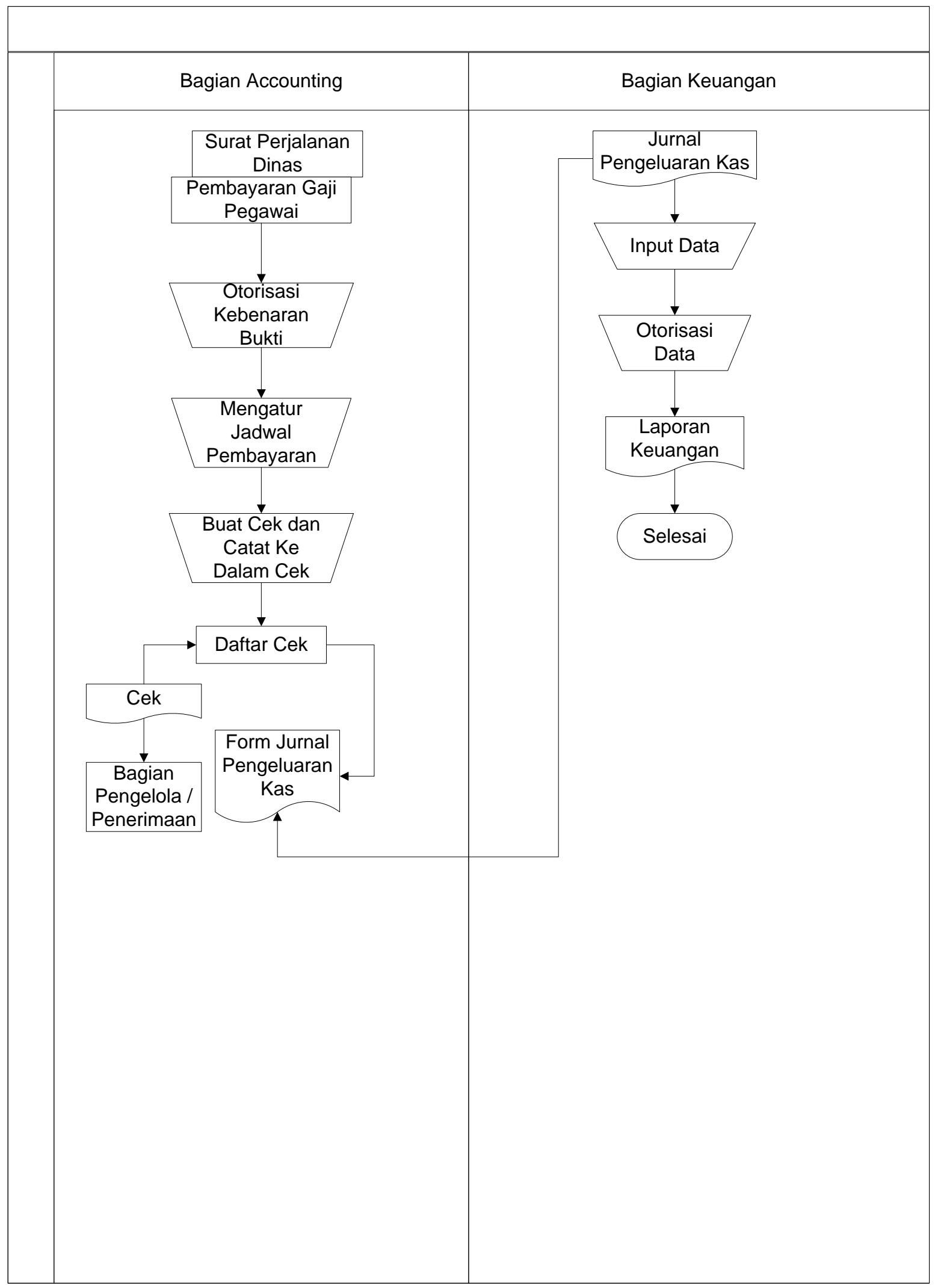

Gambar 3.3

Alur Prosedur Pengeluaran Kas Pusat Penelitian dan Pengembangan Peternakan 


\section{Keterangan:}

\section{Bagian Kas}

Pada Bagian Kas ini dihimpun segala hal yang menyangkut pengeluaran kas seperti dana untuk perjalanan dinas, pembayaran gaji karyawan/pegawai, membeli perlengkapan dan peralatan segala aktifitas operasional perusahaan. Setelah itu Bagian Kas melakukan pengecekan ulang kebenaran data tersebut lalu membuat jadwal pembayaran segala pengeluaran dan membuat pengajuan kas bulanan untuk seluruh pengeluaran bulanan (pembayaran gaji karyawan/pegawai, pembayaran untuk membeli perlengkapan dan peralatan, anggaran untuk perjalanan dinas dan pembelian tunai untuk satu tahun) yang disesuaikan dengan rencana anggaran tahunan untuk diajukan kepada pimpinan, cek beserta tanda terima diberikan kembali kepada Bagian Kas untuk diatur pemberian cek tersebut kepada bagian yang menerima.

\section{Bagian Akuntansi}

Setelah menerima jurnal pengeluaran kas, Bagian Akuntansi melakukan penginputan data sesuai dengan yang tertera didalam jurnal pengeluaran kas tersebut.

Selain pembayaran kepada Bagian Penerima dan pengelola, pengeluaran kas juga dilakukan Pusat Penelitian dan Pengembangan Peternakan juga untuk pembayaran gaji dan pembelian perlengkapan peralatan serta kebutuhan aktifitas operasional perusahaan setiap harinya. Pusat Penelitian dan Pengembangan Peternakan menggunakan sistem dana kas kecil tidak tetap yang dipegang oleh Bagian Kas, dimana kas diisi sesuai dengan perkiraan pengeluaran tahunan yang diajukan setiap awal tahun dengan otorisasi dari pimpinan yang bersangkutan. 


\section{BAB IV \\ KESIMPULAN DAN SARAN}

\subsection{Kesimpulan}

Simpulan akuntansi penerimaan dan pengeluaran kas pada Pusat Penelitian dan Pengembangan Peternakan secara umum baik. Tetapi bila membandingkan Standar Akuntansi sistem yang digunakan belum cukup baik. Untuk melaksanakan sistem akuntansi penerimaan kas Pusat Penelitian dan Pengembangan Peternakan yaitu dengan adanya perencanaan kegiatan anggaran kedepan, sedangkan akuntansi pengeluaran kasnya digunakan untuk keperluan pihak intern perusahaan maupun kegiatan operasional.

Dari pembahasan bab-bab sebelumnya dapat disimpulkan bahwa:

1. Sistem penerimaan kas pada Pusat Penelitian dan Pengembangan Peternakan yaitu dari tersedianya anggaran dari pemerintah dilakukan melalui transfer ke bank perusahaan. Fungsi yang terkait dalam penerimaan kas adalah fungsi keuangan, fungsi kas yang merangkap sebagai fungsi tersedianya dan bagian accounting yang melakukan penginputan untuk menghasilkan suatu laporan keuangan perusahaan.

2. Sistem pengeluaran kas pada Pusat Penelitian dan Pengembangan Peternakan dilakukan dengan cek untuk pembayaran segala keperluan yang berhubungan dengan aktifitas operasional perusahaan dan kegiatan sehari-hari perusahaan dana kas kecil, sistem dana kas kecil yang digunakan adalah sistem dana kas kecil tidak tetap yang dpegang oleh bagian kas. Fungsi yang terkait dalam sistem pengeluaran kas adalah fungsi pembayaran keperluan kegiatan perusahaan, pembayaran gaji karyawan, pembayaran pembelian perlengkapan dan peralatan, fungsi kas dan fungsi accounting. Untuk fungsi kas masih ada penggabungan fungsi yaitu sebagai bagian penerimaan, pemegang dana kas besar dan dana kas kecil.

\subsection{Saran}

Dari pembahasan yang dilakukan dalam Tinjauan Sistem Pengendalian Intern Terhadap Penerimaan dan Pengeluaran Kas pada Pusat Penelitian dan Pengembangan Peternakan saran yang diberikan penulis:

"Dilaksanakannya fungsi pembagian tugas yang sesuai dengan fungsi pengeluaran, fungsi keuangan dan fungsi akuntansi hendaknya dipisah untuk mengurangi resiko penyelewengan dalam perusahaan." 


\section{DAFTAR PUSTAKA}

Akmal.2009. Pemeriksaan Manajemen Internal Audit. Indeks. Jakarta

Dody.2009. Evaluasi Sistem Pengendalian Intern Terhadap Penerimaan dan Pengeluaran Kas. Tugas Akhir. Surakarta

Efendy. Arief 2007. Pengertian Audit Internal Menurut International Standards for The Professional Practice of Internal Audit (Diakses 27 September 2012). dari http://muharieffendi.wordpress.com

Frederick D.S. Choi.2010. Salemba Empat. 2010, Newyork., 2010.

Ikatan Akuntan Indonesia.2014. Standar Akuntansi Keuangan per efektif 1 Jan 2015, Indonesia., 2014.

Mulyadi.2008. Auditing Jilid 2. Salemba Empat. Jakarta

Ray. H. Garrison., Erick. W. Noreen., Peter C. Brewer.2013. Salemba Empat edisi 14.2011, Indonesia., 2013.

Puspitasari, R., 2012. Analisa Laporan Keuangan Guna Mengukur Kinerja Keuangan PT Astra Internasional Tbk. Jurnal STIE Kesatuan.

Sofyan Syafri Harahap.2011. Teori Akuntansi, Indonesia., 2012.

Sugiyono.2012. Metode Penelitian Bisnis. Alfabeta. Bandung.

Stice and Skousen.2007. Standar Akuntansi Keuangan. 2005.

Puspitasari, R., 2009. Analisis sumber dan penggunaan modal kerja terhadap modal kerja (SBI Rate and Dollar Exchange Rate). Jurnal Ilmiah Kesatuan, 11(2), pp.49-52.

Hidayat, L. and Mhaydaly, S., 2008. Analisis Risiko Dan Arus Kas Terhadap IRR: Studi kasus pada PT. Dharmala Intiland Tbk, PT. Duta Pertiwi Tbk dan PT. Kawasan Industri Jababeka Tbk. Jurnal Ilmiah Ranggagading (JIR), 8(1), pp.51-58.

Haryanti, A., Muktiadji, N. and Setiana, A., 2013. Analisis Dividen Tunai dan Earning Per Share Terhadap Tingkat Imbal Hasil Investor.

Djanegara, M.S., Nurruzzaman, M. and Kesatuan, D.T.A.M., 2006. ANALISIS NET WORKING CAPITAL DENGAN METODE DAYS OF INVENTORY DAN DAYS OF ACCOUNT RECEIVABLE. Jurnal Ilmiah Kesatuan Nomor, 8(19), p.1.

Pamungkas, B., 2008. Akuntabilitas Instansi Pemerintah. Survei Pada Pemerintah Dati II DI Yogyakarta.

Sutarti, S. and Prayitno, D., 2007. Analisis PSAK No. 45 dalam penyajian Laporan Keuangan Organisasi Nirlaba Studi Kasus pada Rumah Sakit" X". Jurnal Ilmiah Ranggagading (JIR), 7(1), pp.30-36.

Rosita, S.I., 2014. Pengaruh Sistem Bagi Hasil Deposito Mudharabah Terhadap Minat Nasabah Berinvestasi Pada Bank Syariah. Jurnal Ilmiah Akuntansi Kesatuan, 2(1), pp.085-098.

Setiawan, H. and Lisias, V., 2009. Evaluasi atas harga pokok produk sampingan dalam kaitannya dengan perhitungan laba perusahaan (study kasus pada CV. Morinda House Bogor). Jurnal IImiah Ranggagading (JIR), 9(2), pp.85-91.

Rusdiyana, R. and Munawar, A., 2012. ANALISIS PENGELOLAAN AKTIVA TERHADAP KINERJA PENDAPATAN PER LEMBAR SAHAM (EPS). Jurnal Online MahasiswaManajemen, 1(2). 
Munawar, A., 2010. Analisis Nilai Tambah Dan Pemasaran Kayu Sengon Gergajian (Studi Kasus di Kecamatan Cigudeg Kabupaten Bogor).

Purba, J.H.V., 2001. Keragaan Kelapa Sawit Indonesia Ditinjau dari Jenis Pengusahaan dan Wilayah Produksi (Doctoral dissertation, Tesis Magister Sains. Program Pascasarjana, Institut Pertanian Bogor, Bogor).

Munawar, A. and Purba, J.H.V., 2006. Kajian Dampak Pelatihan terhadap Kinerja Karyawan. Jurnal IImiah Kesatuan Nomor, 8(7), p.2.

Meliana, S. and Setiawan, B., 2013. Pengaruh Kualitas Pelayanan dan Kepercayaan Konsumen Terhadap Keputusan Pembelian. Ilmiah Manajemen Kesatuan, 1, pp.247-254. Supriadi, Y. and Sofyana, A., 2012. Analisis Pengaruh Likuiditas dan Solvabilitas terhadap Rentabilitas pada Koperasi Karyawan PLN Cipta Usaha. Jurnal Ilmiah Ranggagading (JIR), 12(2), pp.186-192. 
Buku Kas Umum pada Bank Pusat Penelitian dan Pengembangan Peternakan Bulan Juli 2015

\begin{tabular}{|c|c|l|c|c|c|}
\hline No & $\begin{array}{c}\text { No } \\
\text { Bukti }\end{array}$ & \multicolumn{1}{|c|}{ Uraian } & $\begin{array}{c}\text { Penerimaan } \\
\text { Kas }\end{array}$ & $\begin{array}{c}\text { Pengeluaran } \\
\text { Kas }\end{array}$ & Sisa \\
\hline 1 & $\begin{array}{c}2240 / 0 \\
7 / 15\end{array}$ & $\begin{array}{l}\text { Jumlah saldo bulan } \\
\text { lalu }\end{array}$ & 10.900 .585 & 10.711 .145 & 189.439 .641 \\
\hline
\end{tabular}




\begin{tabular}{|c|c|c|c|c|c|}
\hline 2 & $\begin{array}{c}2241 / 0 \\
7 / 15\end{array}$ & $\begin{array}{l}\text { SP2D } \\
\text { 150231301010119, } \\
\text { SPM } 00118 \text { (LS } \\
\text { Honor) }\end{array}$ & 16.338 .500 & - & 205.778 .141 \\
\hline 3 & $\begin{array}{c}2242 / 0 \\
7 / 15\end{array}$ & $\begin{array}{l}\text { SP2D } \\
\text { 150231301010111, } \\
\text { SPM } 00119 \text { (LS hnr) }\end{array}$ & 31.200 .000 & - & 236.978 .141 \\
\hline 4 & $\begin{array}{c}2243 / 0 \\
7 / 15\end{array}$ & $\begin{array}{l}\text { SP2D } \\
150231301010112, \\
\text { SPM } 00120 \text { (LS } \\
\text { Honor) }\end{array}$ & 665.000 & - & 237.643 .141 \\
\hline 5 & $\begin{array}{c}2244 / 0 \\
7 / 15\end{array}$ & $\begin{array}{l}\text { SP2D } \\
\text { 150231301010130, } \\
\text { SPM } 00121 \text { (LS } \\
\text { Honor) }\end{array}$ & 2.282 .500 & - & 239.925 .641 \\
\hline 6 & $\begin{array}{c}2245 / 0 \\
7 / 15\end{array}$ & $\begin{array}{l}\text { SP2D } \\
\text { 150231301010131, } \\
\text { SPM } 00123 \text { (LS Perj } \\
\text { dinas) }\end{array}$ & 133.136 .897 & - & 373.062 .538 \\
\hline 7 & $\begin{array}{c}2246 / 0 \\
7 / 15\end{array}$ & $\begin{array}{l}\text { SP2D } \\
\text { 150231301010132, } \\
\text { SPM } 00124 \text { (LS } \\
\text { Honor) }\end{array}$ & 18.878 .700 & - & 391.941 .238 \\
\hline 8 & $\begin{array}{c}2247 / 0 \\
7 / 15\end{array}$ & $\begin{array}{l}\text { SP2D } \\
150231301010117, \\
\text { SPM } 00125 \text { (LS } \\
\text { Honor) }\end{array}$ & 2.490 .000 & - & 394.431 .238 \\
\hline 9 & $\begin{array}{c}2248 / 0 \\
7 / 15\end{array}$ & $\begin{array}{l}\text { SP2D } \\
\text { 150231301010118, } \\
\text { SPM } 00126 \text { (LS } \\
\text { Honor UPSUS) }\end{array}$ & 23.895 .000 & - & 418.326 .238 \\
\hline 10 & $\begin{array}{c}2249 / 0 \\
7 / 15\end{array}$ & $\begin{array}{l}\text { PU Bank No cek CFB } \\
870648 \text { (Uang LS } \\
\text { Honor, perj dinas) }\end{array}$ & - & 228.886 .597 & 189.439 .641 \\
\hline 11 & $\begin{array}{c}2278 / 0 \\
7 / 15\end{array}$ & $\begin{array}{l}\text { SP2D } \\
\text { 150231301010189, } \\
\text { SPM } 00128 \text { (LS Perj } \\
\text { dinas) }\end{array}$ & 56.984 .000 & - & 246.423 .641 \\
\hline 12 & $\begin{array}{c}2279 / 0 \\
7 / 15\end{array}$ & $\begin{array}{l}\text { SP2D } \\
\text { 150231301010188, } \\
\text { SPM } 00127 \text { (LS Perj } \\
\text { dinas) }\end{array}$ & 3.646 .000 & - & 250.069 .641 \\
\hline
\end{tabular}

Sumber : Bagian Keuangan Pusat Penelitian dan Pengembangan Peternakan

Buku Kas Umum Tunai pada Pusat Penelitian dan Pengembangan Peternakan

Bulan Juli 2015

\begin{tabular}{|c|c|c|c|c|c|}
\hline No & No Bukti & Uraian & Penerimaan & Pengeluaran & Sisa \\
\hline 1 & $2249 / 07 / 1$ & Jumlah saldo bulan & 12.904 .866 .873 & 12.861 .190 .93 & 43.675 .943 \\
\hline
\end{tabular}




\begin{tabular}{|c|c|c|c|c|c|}
\hline & 5 & Ialu & & & \\
\hline 2 & $\begin{array}{c}2250 / 07 / \\
15\end{array}$ & $\begin{array}{l}\text { Kembali pers. } \\
\text { biaya } \\
\text { bahan/atk,perj.din } \\
\text { as,kons.\& honor } \\
24 / 07 / 15 \text { an } \\
\text { Ridwan }\end{array}$ & - & 410.000 & 43.265 .943 \\
\hline 3 & $\begin{array}{c}2251 / 07 / \\
15\end{array}$ & $\begin{array}{l}\text { Perj dinas ke } \\
\text { Jakarta } 29 / 07 / 15 \\
\text { an Deni Supriadi }\end{array}$ & - & 150.000 & 43.115 .943 \\
\hline 4 & $\begin{array}{c}2252 / 07 / \\
15\end{array}$ & $\begin{array}{l}\text { Perj dinas ke } \\
\text { Lampung } 28- \\
29 / 07 / 15 \text { an Umi } \\
\text { A. }\end{array}$ & - & 150.000 & 42.965 .943 \\
\hline 5 & $\begin{array}{c}2253 / 07 / \\
15\end{array}$ & $\begin{array}{l}\text { Perj dinas ke } \\
\text { Lampung 28- } \\
29 / 07 / 15 \text { an } \\
\text { Artaria M }\end{array}$ & - & 150.000 & 42.815 .943 \\
\hline 6 & $\begin{array}{c}2254 / 07 / \\
15\end{array}$ & $\begin{array}{l}\text { Perj dinas ke } \\
\text { Lampung } 28- \\
29 / 07 / 15 \text { an } M \\
\text { Indra Fauzi }\end{array}$ & - & 1.122 .000 & 41.693 .943 \\
\hline 7 & $\begin{array}{c}2255 / 07 / \\
15\end{array}$ & $\begin{array}{l}\text { Perj dinas ke } \\
\text { Lampung } 28- \\
29 / 07 / 15 \text { an Wisri } \\
\text { Puastuti }\end{array}$ & - & 250.000 & 41.443 .943 \\
\hline 8 & $\begin{array}{c}2256 / 07 / \\
15\end{array}$ & $\begin{array}{l}\text { Perj dinas ke } \\
\text { Lampung 28- } \\
29 / 07 / 15 \text { an Didik } \\
\text { Tulus S }\end{array}$ & - & 288.411 & 41.155 .532 \\
\hline 9 & $\begin{array}{c}2257 / 07 / \\
15\end{array}$ & $\begin{array}{l}\text { Perj dinas ke } \\
\text { Lampung } 28- \\
29 / 07 / 15 \text { an } \\
\text { Nurhayati }\end{array}$ & - & 250.000 & 40.905 .532 \\
\hline 10 & $\begin{array}{c}2258 / 07 / \\
15\end{array}$ & $\begin{array}{l}\text { Perj dinas ke } \\
\text { Lampung Timur } \\
28-29 / 07 / 15 \text { an } \\
\text { Marsudin S. }\end{array}$ & - & 286.000 & 40.619 .532 \\
\hline 11 & $\begin{array}{c}2259 / 07 / \\
15\end{array}$ & $\begin{array}{l}\text { Biaya konsumsi } \\
\text { snack pelatihan } \\
\text { manajemen } \\
29 / 07 / 15 \text { an RM } \\
\text { Soto Seger }\end{array}$ & - & 150.000 & 40.469 .532 \\
\hline 12 & $\begin{array}{c}2260 / 07 / \\
15\end{array}$ & $\begin{array}{l}\text { Biaya konsumsi } \\
\text { makan pelatihan } \\
\text { manajemen } \\
29 / 07 / 15 \text { an RM } \\
\text { Soto Seger }\end{array}$ & - & 200.000 & 40.269 .532 \\
\hline 13 & $\begin{array}{c}2261 / 07 / \\
15\end{array}$ & $\begin{array}{l}\text { Pembelian kit } \\
\text { pelatiahan } \\
\text { manjemen } \\
27 / 07 / 15 \text { an SPU }\end{array}$ & - & 200.000 & 40.069 .532 \\
\hline 14 & $\begin{array}{c}2262 / 07 / \\
15\end{array}$ & $\begin{array}{l}\text { Pemb. } \\
\text { Sertifikat, spanduk } \\
\text { pelatihan } \\
\text { manajemen } \\
27 / 07 / 15 \text { an Prima } \\
\text { Jaya }\end{array}$ & - & 415.500 & 39.654 .032 \\
\hline 15 & 2263/07/ & $\begin{array}{l}\text { Biaya konsumsi } \\
\text { makan rpt }\end{array}$ & - & 200.000 & 39.454 .032 \\
\hline
\end{tabular}




\begin{tabular}{|c|c|c|c|c|c|}
\hline & 15 & $\begin{array}{l}\text { bioindustri } \\
24 / 07 / 15 \text { an Ayam } \\
\text { Geprek }\end{array}$ & & & \\
\hline 16 & $\begin{array}{c}2264 / 07 / \\
15\end{array}$ & $\begin{array}{l}\text { Biaya konsumsi } \\
\text { snack rpt IACUC } \\
27 / 07 / 15 \text { an } \\
\text { Anugrah } \\
\end{array}$ & - & 200.000 & 39.254 .032 \\
\hline 17 & $\begin{array}{c}2265 / 07 / \\
15\end{array}$ & $\begin{array}{l}\text { Biaya konsumsi } \\
\text { makan rpt evaluasi } \\
\text { hsl survey } \\
29 / 07 / 15 \text { an Ayam } \\
\text { Geprek }\end{array}$ & - & 415.500 & 38.838 .532 \\
\hline 18 & $\begin{array}{c}2266 / 07 / \\
15\end{array}$ & $\begin{array}{l}\text { Biaya konsumsi } \\
\text { snack rpt evaluasi } \\
\text { hsl survey } \\
29 / 07 / 15 \text { an } \\
\text { Anugrah }\end{array}$ & - & 1.890 .000 & 36.948 .532 \\
\hline 19 & $\begin{array}{c}2267 / 07 / \\
15\end{array}$ & $\begin{array}{l}\text { Honor narasumber } \\
\text { pelatihan } \\
\text { manajemen } \\
29 / 07 / 15 \text { an Wisri }\end{array}$ & - & 1.890 .000 & 35.058 .532 \\
\hline 20 & $\begin{array}{c}2268 / 07 / \\
15\end{array}$ & $\begin{array}{l}\text { Honor narasumber } \\
\text { pelatihan } \\
\text { manajemen } \\
29 / 07 / 15 \text { an Didik } \\
\text { Tulis S }\end{array}$ & - & 2.222 .000 & 32.836 .532 \\
\hline 21 & $\begin{array}{c}2269 / 07 / \\
15\end{array}$ & $\begin{array}{l}\text { Honor narasumber } \\
\text { pelatihan } \\
\text { manajemen } \\
29 / 07 / 15 \text { an } \\
\text { Nurhayati }\end{array}$ & - & 1.890 .000 & 30.946 .532 \\
\hline 22 & $\begin{array}{c}2269 / 07 / \\
15\end{array}$ & $\begin{array}{l}\text { Honor narasumber } \\
\text { pelatihan } \\
\text { manajemen } \\
29 / 07 / 15 \text { an Umi } \\
\text { Adiati }\end{array}$ & - & 497.500 & 30.449 .032 \\
\hline 23 & $\begin{array}{c}2270 / 07 / \\
15\end{array}$ & $\begin{array}{l}\text { Perj dinas ke } \\
\text { Jakarta 30/07/15 } \\
\text { an Mardan }\end{array}$ & - & 180.000 & 30.269 .032 \\
\hline 24 & $\begin{array}{c}2271 / 07 / \\
15\end{array}$ & $\begin{array}{l}\text { Perj dinas ke } \\
\text { Jakarta } 30 / 07 / 15 \\
\text { an Nana } \\
\text { Supriyatna }\end{array}$ & - & 1.500 .000 & 28.769 .032 \\
\hline 25 & $\begin{array}{c}2272 / 07 / \\
15\end{array}$ & $\begin{array}{l}\text { Perj dinas ke } \\
\text { Jakarta } 29 / 07 / 15 \\
\text { an Mardan }\end{array}$ & - & 200.000 & 28.569 .032 \\
\hline 26 & $\begin{array}{c}2273 / 07 / \\
15\end{array}$ & $\begin{array}{l}\text { Biaya konsumsi rpt } \\
\text { rutin } 15 / 07 / 15 \text { an } \\
\text { Ayam Geprek }\end{array}$ & - & 360.000 & 28.209 .032 \\
\hline 27 & $\begin{array}{c}2274 / 07 / \\
15\end{array}$ & $\begin{array}{l}\text { Biaya } \\
\text { penggandaan lap } \\
\text { bulanan 03/08/15 } \\
\text { an Yasmin FC }\end{array}$ & - & 200.000 & 28.009 .032 \\
\hline 28 & $\begin{array}{c}2275 / 07 / \\
15\end{array}$ & $\begin{array}{l}\text { Biaya cetak digital } \\
\text { pedoman teknis } \\
\text { SPI } 04 / 08 / 15 \text { an } \\
\text { OK Print }\end{array}$ & - & 277.500 & 27.731 .532 \\
\hline 29 & $\begin{array}{c}2276 / 07 / \\
15\end{array}$ & $\begin{array}{l}\text { Perj dinas ke } \\
\text { Sentul 29/07/15 } \\
\text { an Atien Priyanti }\end{array}$ & - & 150.000 & 27.581 .532 \\
\hline 30 & 2277/07/ & $\begin{array}{l}\text { Perj dinas ke } \\
\text { Sentul } 29 / 07 / 15\end{array}$ & - & 150.000 & 27.431 .532 \\
\hline
\end{tabular}




\begin{tabular}{|c|c|l|c|c|c|}
\hline & 15 & an Taswin & & \\
\hline 31 & $2278 / 07 /$ & $\begin{array}{l}\text { PU Bank No cek } \\
\text { CFB 870648 (Uang } \\
\text { LS Honor, perj } \\
\text { dinas) }\end{array}$ & - & 14.960 .000 & 12.471 .532 \\
\hline 32 & $2279 / 07 /$ & Jumlah dipindahkan & 12.904 .866 .873 & 12.892 .395 .341 & 12.471 .532 \\
\hline
\end{tabular}

Sumber : Bagian Keuangan Pusat Penelitian dan Pengembangan Peternakan 